NBER WORKING PAPER SERIES

\title{
THE EFFECTS OF LEVERAGED BUYOUTS ON PRODUCTIVITY AND RELATED ASPECTS OF FIRM BEHAVIOR
}

Frank R. Lichtenberg

Donald Siegel

Working Paper No. 3022

\author{
NATIONAL BUREAU OF ECONOMIC RESEARCH \\ 1050 Massachusetts Avenue \\ Cambridge, MA 02138 \\ June 1989
}

This study was supported by the Securities Industry Association. The research, conducted at the Center for Economic Studies, U.S. Bureau of the Census, was based on earlier work supported by the National Science Foundation under Interagency agreement SRS-8801036, "Industrial R\&D and Productivity: Using an expanded NSF/Census Data Linkage File." This paper is part of NBER's research program in Productivity. Any opinions expressed are those of the authors not those of the National Bureau of Economic Research, the Securities Industry Association, the U.S. Bureau of the Census, or the National Science Foundation. 
NBER Working Paper \#3022

June 1989

THE EFFECTS OF LEVERAGED BUYOUTS ON PRODUCTIVITY AND RELATED ASPECTS OF FIRM BEHAVIOR

\begin{abstract}
We investigate the economic effects of leveraged buyouts (LBOs) using large longitudinal establishment and firm-level Census Bureau data sets linked to a list of LBOs compiled from public data sources. About 5 percent, or 1100 , of the manufacturing plants in the sample were involved in LBOs during 1981-86. We find that plants involved in LBOs had significantly higher rates of totalfactor productivity (TFP) growth than other plants in the same industry. The productivity impact of LBOs is much larger than our previous estimates of the productivity impact of ownership changes in general. Management buyouts appear to have a particularly strong positive effect on TFP.

Labor and capital employed tend to decline (relative to the industry average) after the buyout, but at a slower rate than they did before the buyout. The ratio of nonproduction to production labor cost declines sharply, and production worker wage rates increase, following LBOs. LBOs are production-labor-using, nonproduction-labor-saving, organizational innovations. Plants involved in management buyouts (but not in other LBOs) are less likely to subsequently close than other plants. The average R\&D-intensity of firms involved in LBOs increased at least as much from 1978 to 1986 as did the average $R \& D$-intensity of all firms responding to the NSF/Census survey of industrial $R \& D$.
\end{abstract}

Frank R. Lichtenberg National Bureau of Economic Research and Columbia University

726 Uris Hall

New York, NY 10027
Donald Siegel

National Bureau of Economic Research 1050 Massachusetts Avenue Cambridge, MA 02138 


\section{Introduction}

In a previous study (Lichtenberg and Siegel (1987)), we examined the relationship between productivity and changes in ownership (commonly referred to as "mergers and acquisitions") of U.S. manufacturing plants during the $1970 \mathrm{~s}$. We found that the least productive plants in an industry are most likely to subsequently change owners, and that following ownership change, these plants tend to experience above-average improvements in productivity. A more recent paper (Lichtenberg and Siegel (1989a)) indicated that changes in ownership are associated with substantial reductions in administrative overhead -- measured by the ratio of "central-office" (auxiliary-establishment) employees to plant employees -- and that this is a major source of takeover-related productivity gains.

The purpose of this paper is to investigate the effects of a specific, and increasingly important, type of ownership change -- the leveraged buyout (LBO) -- on total-factor productivity and related aspects of firm behavior. In an LBO, a group of investors (which sometimes includes incumbent management) takes a company (or a division of a company) private by purchasing all of the outstanding equity of the company, mainly using borrowed funds. The enterprise is much more highly leveraged (it has a higher debt/equity ratio) after the LBO than before. The financing of LBOs often involves the sale of high-yield (or "junk") bonds. The debt incurred to buy out the company is expected to be serviced by a combination of operating income and asset sales.

Although the LBO transaction has been in existence for at least 20 years, only in the 1980 s has it become a quantitatively significant component of overall merger and acquisition (M\&A) activity. The share of 
LBOs in the aggregate value of M\&A transactions increased from almost zero in the 1970 s to 27 percent in 1986. This increase is probably attributable to an important extent to the invention and diffusion of junk bond financing beginning in the late 1970s. Because the extent of LBO activity was negligible prior to about 1981 , our analysis will focus primarily on the period 1981-86. 1986 is the latest year for which Census data were available; this is unfortunate because most of the LBOs during this period occurred in the last three years. This limits our ability to measure behavior in the years following the LBO. Nevertheless, our sample is large enough that we can obtain reasonably precise estimates for at least two years following the buyout.

One major advantage of the Census Bureau data sets is that they, unlike publicly available data sources, include observations on privately as well as publicly owned firms and establishments. As noted above, firms that have undergone an LBO are (at least initially) ${ }^{1}$ privately held. Privately-held companies are generally not required by the Securities and Exchange Commission (SEC) to issue financial data, which clearly poses a problem for assessing post-buyout performance. 2

1 A number of firms involved in LBOs subsequently underwent "reverse LBOs," i.e. they became (or were acquired by) publicly-held companies, especially after 1986. See Forbes, March 20, 1989, pp. 210-211.

2 Under special circumstances, such data may be available. Smith (1989) obtained data on post-buyout corporate performance for only 58 out of 215 management buyouts from the following sources: prospectuses issued by 17 companies with a subsequent offering of common stock; other SEC filings of 32 companies with public debt or preferred stock outstanding after the MBO; and financial statements released confidentially by 9 companies. As Smith acknowledges, there is a strong possibility that the 58 companies for which data are available are not a random sample of all 215 companies, and therefore that the findings based on this subset are biased, although she makes a fairly convincing case that her results are not 
A second important advantage of the establishment-level Census data is that they enable us to analyze partial-firm (subsidiary) LBOs. 46 percent of the LBOs in our sample were of divisions of firms rather than entire firms. Because data at the divisional or lower level are not generally publicly available -- even for publicly-held firms -- previous studies (e.g. Kaplan (1988), Smith (1989)) have had to confine their attention to buyouts of entire firms. Moreover, LBOs are frequently followed by divestiture of some of the firm's plants or lines of business, further limiting the usefulness of company-level data.

Our primary objective is to analyze the relationship between LBOs and total factor productivity -- output per unit of total input -although we will also consider the effects of LBOs on other, related, aspects of firm behavior such as output, employment, capital stock, wages, plant closings, and R\&D investment. TFP is perhaps the single best measure of technical efficiency, and in his pioneering studies in the 1950s Robert Solow (1957) established that most of the long-run increases in economic welfare (output per capita) experienced by the U.S. and other industrialized countries have been due to increases in TFP.

Acquisition of a firm via leveraged buyout might be expected to result in an increase in its relative TFP because compensation (of senior managers and perhaps of other employees as well) -- and indeed the very survival of the firm -- is much more strongly related to performance

seriously affected by sample-selection bias. Nevertheless, it is clearly preferable to conduct the analysis using a data set not subject to this kind of censoring.

As we discuss below the extract of the Census Longitudinal Research Database (LRD) we use is also subject to censoring, albeit of a different, presumably less important, kind. 
after the buyout than before. Jensen (1989, p. 5) states that the average CEO in a sample of LBOs receives at least $\$ 64$ per $\$ 1000$ change in shareholder wealth from his typical $6.4 \%$ equity interest, whereas the average $C E O$ in the Forbes 1000 firms experiences total wealth change of about $\$ 2$ per $\$ 1000$ change in stockholder value. If the firm's earnings are insufficient to cover the interest payment on the debt incurred to finance the buyout, the managers also face the risk of losing control of the firm to the bondholders. This increases the rewards for strong performance (and increases the penalty for poor performance). Jensen has also argued that large fixed interest obligations, by reducing the amount of "free cash flow," reduce the likelihood and extent of investment in "unproductive" projects. Thus changes in both the incentives and opportunities facing managers are hypothesized to lead to improvements in productivity. 3

The remainder of this paper is organized as follows. In the next section we document the growth in LBO activity in greater detail and describe the construction of our data base. The development and analysis of the TFP measure is presented in Section III. The decomposition of TFP changes into output and input changes is reported in Section IV. Relative rates of plant closings among LBO and non-LBO plants, and their possible implications, are discussed in Section V. Section VI is devoted

3 While the LBO organizational form may generate higher average economic "returns" (productivity) than the prototypical public corporation, it is also subject to greater (financial) risk. One view of the rise of LBOs is that the higher potential returns to this organizational form were more than sufficient to compensate investors for their higher risk. Our empirical work is aimed at determining the difference in mean returns (productivity), but not the difference in risk, between LBO and non-LBO firms or plants. 
to an analysis of the effects of LBOs on R\&D investment. A summary and concluding remarks are given in the last section.

\section{Linking Census data to the external list of LBOS}

Table 1 presents annual data published by Mergers and Acquisitions magazine on the aggregate value and number of LBOs for the years 1981-86. (Prior to 1981, the extent of LBO activity was apparently very limited. There were only 3 LBOs of at least $\$ 35$ million in value in both 1979 and 1980 , and in both years the aggregate value was under $\$ 1$ billion.) Also included in Table 1 as a benchmark are data published by W.T. Grimm and Co. on all merger and acquisition (M\&A) transactions. Both the number and total value (but not the average value) of LBOs increased in every year. The largest jumps in value occurred in 1984 and 1986 , and probably reflect a few very large transactions. Between 1981 and 1986, the number of LBOs more than tripled, and their total value increased more than fifteen-fold. The number and value of M\&As also tended to increase during this period (following a period of steady decline since 1969), but at a much lower rate. The number of M\&As increased 39 percent, and their nominal value less than tripled. Between 1981 and 1986, the LBO share of the number of deals increased from 4.1 percent to 10.0 percent, and the LBO share of the total value increased from 3.7 percent to 26.9 percent. In the first three years the average size of LBO transactions tended to be somewhat smaller than that of all M\&A transactions, but in the last three years have tended to be considerably larger.

Unfortunately, we had access to data on individual LBOs only for LBOs whose value was at least $\$ 35$ million (henceforth referred to as 
"major LBOs"). The bottom panel of Table 1 presents data for this subset of deals. 4 In principle, of course, the total value of major LBOs cannot exceed the total value of all LBOs, but the data for the two groups come from different sources which in some cases assign different values to a given deal, so this inequality is sometimes violated in practice. Nevertheless, comparison of the top and bottom panels of the table provides a rough guide to the effect of the $\$ 35$ million threshhold. For the period as a whole, major LBOs account for 19 percent of the deals but for 96 percent of the total value. Because the same nominal threshold was in effect in every year, the fraction of deals exceeding the threshhold (hence observed by us) tended to be larger towards the end of the period.

In order to assess the effect of LBOs on the performance and conduct of the firms involved, we linked the data contained in the list of major LBOs to an extract we prepared of data on individual manufacturing establishments contained in the Census Bureau's LRD. 5

4 Data on these individual LBOs were provided to us by Morgan Stanley and Co., which compiles its own exhaustive database of all major mergers and acquisitions, of which LBOs are a subset. The primary sources from which the database is compiled are reports in the New York Times, The Wall Street Journal, Dow Jones Tapes, and news releases. Transactions are identified as LBOs in the Morgan Stanley database if they are reported as such in the primary sources. We did not have access to data on individual M\&As; we present data on MEAs of at least $\$ 35$ million only for purposes of comparison.

5 The IRD is a large micro database of establishment-level data constructed by pooling information from the quinquennial Census of Manufactures and from the Annual Survey of Manufactures. See McGuckin and Pascoe (1988) for a detailed discussion of the LRD. Data for between 310 and 350 thousand establishments are included for each of five Census years (1963, 1967, 1972, 1977, and 1982), and for between 52 and 74 thousand establishments in non-Census years from 1973 to 1986. In our 1987 paper we analyzed data for the years 1972 through 1981 -- the latest year for which data were available at the time. We restricted our sample to include only those establishments that were observed in every one of the ten years 1972-81. Thus plants that opened or closed and plants that 
Roach (1989, p. 24) estimates that 63 percent of the total value of the major LBOs during the period 1978-88 involved companies or divisions whose primary industry is manufacturing. Since only manufacturing establishments (and not, for example, retail and service establishments) are included in the IRD, if the sizes of LBOs in manufacturing and other sectors are similar one would expect to identify establishments in it corresponding to no more than about 60 percent of the (number or value of) LBOs. As Table 2 reveals, we were able to observe one or more establishments of companies involved in 57 percent (by value) of the major LBOs. Thus within the constraints of the deal-size threshhold and the industry (manufacturing only) limitation, the "coverage" provided by the LRD appears to be quite good.

The establishment records in the IRD indicate both a code identifying the establishment's parent company and the (4-digit SIC) industry in which the establishment (primarily) operates. To determine whether an establishment had been involved in an LBO in a particular year, we adopted the following procedure (See Chart 1). We looked to see whether

were admitted or deleted from the ASM sample during the period were excluded from our sample, which as a result contained data for 20,493 establishments. To perform the present study we extended the data for these 20,493 establishments through 1986 using the newly available data for the years 1982-86. We did not include data for plants that were not already present in our earlier file, i.e. we did not include data for plants that opened or were admitted into the ASM sample after 1981. However, to remain in our sample we did not insist that an establishment be observed (operating and in the ASM sample) in each of the years 1982-86. Thus, our panel of establishments is "unbalanced" after 1981, and by 1986 the number of plants has fallen to about 14,300 .

In retrospect, the above procedure for constructing our database was probably not an optimal one, although we doubt that our findings have been strongly influenced by this procedure. We hope in future work to re-examine some of these issues using a more representative database. 
the parent company's name appeared on the list of companies acquired via LBOs in that year. If not, we assigned the code $\mathrm{LBO}=0$ (not involved in an LBO in that year). If so, we determined whether the LBO was of the entire company or only of a part of the company. ${ }^{6}$ If the LBO was of the entire $f(\mathrm{rm}$, the establishment was assigned the code $L B O=1$ (involved in an LBO in that year). If the LBO was of only part of the company, we developed a list of SIC codes of the acquired unit based on a "business description" of the unit contained in the Morgan Stanley database. Additional information about the industrial activities of divisions or companies was obtained from Standard and Poor's Registry of Corporations and the Directory of Corporate Affiliations. If the establishment's SIC code was included in this list, we assigned the code $L B O=1$; otherwise we assigned the code $\angle B O=0$.

Our procedure for assigning values to the LBO code is undoubtedly subject to error, particularly in the case of partial-firm LBOs. For example, if two subsidiaries of a firm both have plants in the same industry, and only one of the subsidiaries is involved in an LBO, then we would erroneously assign the value $L B O=1$ to both subsidiaries' establishments. ${ }^{7}$ If, however, such measurement errors are random (which we expect to be the case), then their effect will be to reduce the magnitude and significance of the estimated differences in behavior between LBO and non-LBO establishments.

6 As Table 3 shows, "partial" LBOs account for 39 percent of all LBOs captured in the LRD file.

7 This may not be a serious problem, however, since McGuckin and Andrews (1988) found that firms rarely divest only some of their plants in a given 4-digit industry. 
Several previous empirical studies (Kaplan (1988) and Smith (1989)) have been concerned with so-called management buyouts (MBOs), the subset of LBOs in which the acquiror includes the incumbent managers of the acquired unit. Since the description of the acquiror indicates whether or not management participated in the acquisition, we can distinguish (albeit perhaps imperfectly) between MBOs and other LBOs. As Table 3 reveals, MBOs accounted for 45 percent of the value of all major LBOs during the period 1981-86..$^{8}$ Among major LBOs captured in our extract of the LRD, however, MBOs accounted for only 27 percent of total value, perhaps because management is less likely to participate in LBOs in manufacturing than in other sectors.

Our extract from the LRD contained data on 20,493 manufacturing establishments for the year 1981. 1108 ( 5.4 percent) of these establishments were involved in at least one major LBO during the period 1981-86. The distribution of establishments involved in major LBOs (henceforth "LBO establishments"), by type of LBO, is presented in Table 4. 35 percent of the LBO establishments were involved in MBOs, and 30 percent were involved in partial-firm LBOs. These two attributes are correlated: MBOs account for 47 percent of partial-firm LBOs but only 30 percent of full-firm LBOs.

The establishment records in the LRD also include a "coverage code" which indicates, among other things, whether or not the owner of the establishment (i.e., the ultimate parent corporation) had changed since the previous year ${ }^{9}$. This coverage code was used to distinguish between

The share of MBOs increased fairly steadily over time.

We also used the coverage code to identify incidents of plant closing. This issue will be discussed in Section $V$. 
establishments changing and not changing owners in our two previous studies $(1987,1989 a)$ of ownership change. Since LBOs constitute a special case of the general phenomenon of ownership change, one might expect that virtually all the establishments that we identified as being involved in LBOs (via the procedure outlined above) would have Census coverage codes indicating a change in ownership in the year of the LBO. We discovered, however, that the measured rate of ownership change during 1981-86 among LBO plants was substantially less than 100 percent -- it was 37 percent - although it was about double the rate among non-LBO plants. Moreover, the higher six-year rate of ownership change among LBO plants was to an important extent accounted for by higher frequency of ownership change in years following the LBO.

Although these findings appear to be anomalous, they may to some extent simply reflect two features of the Census Bureau's procedure for recording ownership change in the plant files. First, the Bureau generally records ownership change only when there is a true merger in the sense that operating units are combined under common ownership or one firm is split into two or more operating units. One would therefore expect there to be a higher measured rate of ownership change among plants involved in partial than in full-firm LBOs, which is in fact the case. $^{10}$ Second, the Bureau obtains ownership information from an independent, firm-level "Report of Organization" and processes it into the plant files with a $1 \frac{1}{2}-2$ year 1ag. Some ownership changes (particularly those involving small firms) are therefore reported as occurring in

10 Plants involved in partial LBOs were about twice as likely to be coded as ownership-change plants as plants involved in full-firm LBOs: the respective ownership change rates were 56 and 29 percent. 
years following the actual ownership change. Also, many of the LBOs occurred in 1985 and 1986, and the ownership information for these years may not have been entered (even with a lag) into the files we analyzed.

III. Comparisons of productivity of buyout and non-buyout plants

In this section we describe and analyze differences in total-factor productivity (TFP) behavior between plants involved in LBOs (or MBOs) and other plants. Our measure of TFP is a (raw or studentized) residual from a production function of the following form, estimated separately by 4-digit SIC industry and year:

$$
\begin{aligned}
\ln V Q_{i j t}=\beta_{0 j t}+\beta_{L j t} \ln L_{i j t} & +\beta_{K j t} \ln K_{i j t} \\
& +\beta_{M j t} \ln V M_{i j t}+u_{i j t}
\end{aligned}
$$

where VQ denotes the value of production (the value of shipments adjusted for changes in finished-goods and work-in-process inventories); L denotes labor input ("production-worker-equivalent" manhours); K denotes capital input (the "perpetual inventory" estimate of the net stock of plant and equipment); VM denotes the value of materials consumed (materials purchased adjusted for changes in raw-materials inventories); $u$ is a disturbance term; and the subscript ijt refers to establishment $i$ in 4-digit SIC industry $j$ in year $t .^{11}$ Output and materials are measured in nominal

11 This (generalized) Cobb-Douglas production function may be regarded as a local first-order logarithmic approximation to any arbitrary production function. Maddala (1979, p. 309) has shown that, at least within a "limited class of functions ... (viz. Cobb-Douglas, generalized Leontief, homogeneous translog, and homogeneous quadratic) differences in the functional form produce negligible differences in measures of multi-factor productivity." This is because these different functional forms differ in their elasticities of substitution (which depends on the second derivatives of the produc- 
terms because the IRD does not include establishment-specific deflators. It is conventional to assume that output and materials prices do not vary across establishments within an industry, which would imply that the nominal measures are proportional to their real counterparts, although there is evidence inconsistent with this hypothesis (see Abbott (1988)) . Thus the computed residual may be capturing price differences as well as productivity differences. Because eq. (1) was estimated separately by industry and year, the residual for a given observation measures the percentage deviation of that establishment's TFP from the mean TFP of all establishments in the same industry and year. By construction, of course, the residuals have a mean value of zero.

Although the production function (1) is estimated separately by industry and year, we will pool the estimated residuals across industries (and sometimes also across years). The estimated residual variance $S_{j t}^{2}=\frac{1}{N_{j t}-4} \sum_{i} e_{i j t}^{2}$ varied over $j$ and $t$, so a given value of a raw residual $e_{i j t}$ represented a larger relative departure from mean productivity in some industries and years (those with "low" $\hat{\mathrm{s}}_{\mathrm{jt}}^{2}$ ) than in others. In addition to examining the raw residuals, we therefore also examined the "studentized" residuals $e_{i j t} / \hat{S}_{j t}$, which are the raw residuals scaled by the corresponding estimated standard error of the regression (1). An observation whose studentized residual is say, 0.5 , has productivity half a standard deviation above average.

Our first approach to assessing the impact of $\mathrm{LBO}$ s on productivity is to estimate the difference in the growth in TFP during 1981-86 between

tion function) whereas productivity depends primarily on the first derivatives. 
plants involved in LBOs during that period and other plants, conditional on the level of productivity in 1981. The coefficient $\gamma_{1}$ from the following regression is an estimate of this difference in growth rates:

$$
Y_{i j 86}=\gamma_{0}+\gamma_{1} X_{i j 81-86}+\gamma_{2} Y_{i j 81}+\varepsilon_{i j 86}
$$

where $\mathrm{Y}$ denotes either the raw residual or the studentized residual, and $X$ denotes either an LBO dummy $(=1$ if the establishment was involved in an LBO during 1981-86, = 0 otherwise) or an MBO dummy (defined similarly). ${ }^{12}$ The coefficient on 1981 productivity is specified as a free parameter rather than constrained to equal unity to allow for the possibility that productivity growth depends on the initial productivity level (i.e., productivity is not a random walk), and for a correlation between $X$ and initial productivity. Estimates of the parameter $\gamma_{1}$ from eq. (2) are reported in Table $5 .{ }^{13}$ Each of the coefficients reported in Table 5 comes from a separate regression. The first line displays estimates based on the raw residual as the productivity measure. It

12 Because $Y_{i j 81}$ is a residual estimated from the first-stage eq. (1) rather than the true but unobserved productivity disturbance, as Murphy and Topel (1985) show the OLS standard errors (t-statistics) are probably biased downward (upward). (The fact that the dependent variable $Y_{i j 86}$ is also estimated apparently doesn't result in any such bias.) We plan in the future to calculate corrected standard errors using their formula for the asymptotic covariance matrix. However one of their empirical illustrations (see p. 373 of their article) suggests that, because the variable $\mathrm{X}_{i j 81-86}$ was excluded from the first-stage eq., the bias in the OLS standard error of $\gamma_{1}$, if any, is small. In their example, it was on the order of 3 percent.

13 Estimates of $\gamma_{2}$ and their corresponding standard errors (in parentheses) are $.879(.022)$ and $.342(.009)$ for the raw and studentized residuals, respectively. The results are the same in the case of the $L B O$ and MBO specifications. 
indicates that the (cumulative) productivity growth during 1981-86 of plants involved in LBOs was 2.8 percentage points higher than that of plants not involved in LBOs; the difference in growth rates is highly statistically significant. 14 The difference in $g$ rowth rates was even higher -- 3.9 percentage points -- in the case of establishments involved in management buyouts. ${ }^{15}$ The estimates based on the studentized residuals are qualitatively similar to those based on the raw residuals: they are highly (indeed slightly more) significant, and the relative magnitudes of the $L B O$ and MBO coefficients are similar. Because the results based on the raw residuals are more easily compared to other productivity data, henceforth we will confine our attention to these. 16

14 About 9.5 percent of LBO plants, and 10.2 percent of non-LBO plants, were not in the same 4-digit industry in 1986 as they were in 1981 . For plants switching industries, the "reference group" for calculating relative productivity changed. We tried to examine whether switching of industries affected our estimates of $\gamma_{1}$ by also including in eq. (2) a dummy variable equal to one if a plant switched industries, and otherwise equal to zero. The coefficient ( $t$-statistic) on this dummy in the raw residual specification was -.011(1.3) -- negative but only marginally significant -- and the estimate of $\gamma_{1}$ was virtually unchanged.

15 We also estimated a version of eq. (2) including two buyout dumy variables, one for management buyouts and one for "other LBOs" (non-management buyouts). The coefficients on "other LBOs" from the raw and studentized residual regressions were respectively $.016(1.30)$ and $.064(1.55)$. Thus they were only marginally significantly different from zero, but we could not reject the hypothesis that the coefficients on MBOs and other LBOs were identical.

16 OLS estimation using studentized residuals is similar to weighted least-squares (WLS) estimation using raw residuals, with weights $\hat{\mathrm{s}}_{\mathrm{ij}}^{-1}$ that are identical for all plants in the same industry in the same year. One might argue that it would be preferable to use weights that vary across plants within industries and years, in particular to use as the weight the reciprocal of the square root of the estimated standard error of the residual

$$
\hat{s}_{j t}^{2}\left(1-x_{i j t}^{\prime}\left(x_{j t}^{\prime} x_{j t}\right)^{-1} x_{i j t}\right)
$$

where $X_{j t}$ is the design matrix from eq. (1) for industry $j$ in year $t$ 
Data published by the Bureau of Labor Statistics (BLS) on TFP growth in the manufacturing sector as a whole provide a convenient, although possibly biased, benchmark against which to measure the LBO-related productivity growth differential cited above. ${ }^{17}$ According to the BLS (1988, p. 12) TFP in the manufacturing sector increased 19.9 percent from 1981 to 1986 . This figure may be considered a weighted average of the productivity growth rates of $L B O$ and non-LBO plants, with weights roughly equal to the fraction of employees in plants in each group:

$$
\begin{aligned}
\pi & =\mathrm{S}_{\mathrm{LBO}} \cdot \pi_{\mathrm{LBO}}+\left(1-\mathrm{S}_{\mathrm{LBO}}\right) \cdot \pi_{\mathrm{NON}-\mathrm{LBO}} \\
& =\pi_{\mathrm{NON}-\mathrm{LBO}}+\mathrm{s}_{\mathrm{LBO}} \cdot\left(\pi_{\mathrm{LBO}}-\pi_{\mathrm{NON}-\mathrm{LBO}}\right)
\end{aligned}
$$

where $\pi, \pi_{L B O}$, and $\pi_{\text {NON-LBO }}$ denote the productivity growth rates of all plants, LBO plants, and non-LBO plants, respectively, and $S_{L B O}$ denotes the fraction of all workers employed in plants that are involved in LBOs, estimated to be 5.25 percent. ${ }^{18}$ The data reported above imply that

and $x_{i j t}$ is the $i^{\text {th }}$ row of this matrix (i.e., the row corresponding to the $i^{\text {th }}$ plant). See Neter et al $(1985, p .402)$ for a derivation of this formula. We have taken this approach in estimating other equations with the same dependent variable as eq. (2) (but different independent variables), and found that relative to OLS estimation using raw residuals, it increased the magnitude of the parameter estimates and $R^{2}$ by 14 to 28 percent and reduced the standard errors by 7 to 15 percent. We therefore plan in the future to apply this procedure to the estimation of eq. (2).

17 We lack output and materials deflators at the 4-digit industry level for the last few years of our sample period. Otherwise, of course, we could compute separate productivity growth rates for both LBO and non-LBO plants, not merely the difference between these growth rates. Since our original (1972-81) sample of plants accounted for 67 percent of aggregate manufacturing shipments (see p. 651 of our 1987 paper), we believe that the BLS number provides a reasonable approximation of average productivity growth in our sample.

18 Equation (2) was estimated using data only for the 14281 plants that had nonmissing data in each of the years 1981-86. 933 (6.5 percent) of these plants were involved in LBOs during that interval. LBO 
$\pi=.199$ and that $\left(\pi_{\text {LBO }}-\pi_{\text {NON-LBO }}\right)=.028$, from which we may infer that $\pi_{\text {NON-LBO }}=.198$ and $\pi_{L B O}=.226$. The productivity growth rate of LBO plants was therefore about 14 percent higher than that of other plants. The productivity growth rate of MBO plants was about 20 percent higher than that of plants not involved in MBOs.

In a previous (1987) paper we estimated the difference in productivity growth rates during 1974-80 between plants involved in ownership changes of all kinds (as measured in the LRD file) and plants not involved in ownership change. The estimated difference $\left(\pi_{O C}-\pi_{N O N-O C}\right)$, although highly significantly different from zero, was considerably smaller than our estimate of $\left(\pi_{\text {LBO }}-\pi_{N O N-L B O}\right):$ it was approximately .005 . However, the overall rate of manufacturing productivity growth during 1974-80 was much lower than it was during 1981-86: productivity increased only 5.6 percent from 1974 to 1980 . Since approximately 15 percent of plants changed owners during the period 1974-80, our previous estimates implied that during that period $\pi_{\text {NON-OC }}=.055$ and $\pi_{\mathrm{OC}}=.060$. Thus the productivity growth rate of plants changing owners was about 9 percent higher than that of plants not changing owners. The percentage difference $\left(\pi_{O C}-\pi_{\text {NON-OC }}\right) / \pi_{\text {NON-OC }}$ is about two-thirds as large as the percentage difference $\left(\pi_{L B O}-\pi_{\text {NON-LBO }}\right) / \pi_{\text {NON-LBO }}$

Our estimates of $\left(\pi_{\mathrm{LBO}}-\pi_{\mathrm{NON}-L B O}\right)$, like our original estimates of $\left(\pi_{O C}-\pi_{N O N-O C}\right)$, are based on data only for operating manufacturing establishments. Due to the unavailability of data, so-called "auxiliary establishments," which include central administrative offices and other

of these plants was 5.5 percent in 1981 and 5.0 percent in 1986 , the mean of which is 5.25 percent. 
nonproduction facilities, were excluded from the econometric analysis in our first paper and in this one. In 1982, auxiliary establishments accounted for about 7 percent of employment and 10 percent of payroll in manufacturing. Unfortunately, data for these establishments are collected only every five years, and the latest year for which they are currently available is $1982 .{ }^{19}$ Auxiliary establishments do not produce any marketable output; rather, they provide services (such as administration, $R \& D$, and data processing) to the firm's production establishments. If the effect of ownership change (or LBO) on employment, for example, in auxiliary establishments is different from its effect in manufacturing establishments, then estimates of the difference $\left(\pi_{O C}-\pi_{\text {NON-OC }}\right.$ ) (or $\left.\left(\pi_{\text {LBO }}-\pi_{\text {NON-LBO }}\right)\right)$ based only on manufacturing establishment data will be biased. In the sequel to our original paper, we showed that ownership change tends to be accompanied by significant (approximately 1 i percent) reductions in the ratio of auxiliary-establishment to productionestablishment employment. Failure to account for this reduction in administrative overhead led to substantial underestimation in our original paper of the effect of ownership change on productivity growth $\left(\pi_{O C}-\pi_{\text {NON-OC }}\right)$. Accounting for this increased our estimate of $\left(\pi_{\mathrm{OC}}-\pi_{\mathrm{NON}-O C}\right)$ by .0034 , from .0046 to .0080 . While we don't have estimates of the effect of LBOs on the ratio $R$ of auxiliary-establishment to production-establishement employment, it is quite plausible that it is as least as negative as the effect of ownership change on $R$. Indeed, statements by Jensen ( 1989, p. 3) imply that the effect may be much greater in magnitude:

19 The 1987 data will probably become available in 1990. 
LBO associations. . are run by partnerships instead of the headquarters office in the typical large multibusiness diversified corporation. These partnerships perform the monitoring and peak coordination function with a staff numbering in the tens of people, and replace the typical corporate headquarters staff of thousands.

If we assume that the effect of LBOs on $R$ is (merely) equal to the effect of ownership change on $R$, we would raise our estimate of $\left(\pi_{L B O}-\pi_{N O N-L B O}\right)$ from .0280 (in Table 5) to .0314 ; if the actual effect on $R$ is larger, even this adjusted figure would understate the true productivity growth differential.

So far we have analyzed the link between LBOs and productivity change by computing the difference in growth rates of TFP over a six year period (1981-86) between plants involved and not involved in LBOs at any time during the period. An alternative approach, which we pursue next, is to compute differences in the mean (level of the) productivity residual in year $t+k(k=-13,-12, \ldots,-1,0,1,2)$ between plants involved and not involved in LBOs in year $t$. This approach has both an advantage and a disadvantage relative to the first approach. The advantage is that it provides evidence concerning the precise timing of productivity movements relative to the date of the LBO. (It is possible, for example, that the higher five-year productivity growth rate of LBO plants is due primarily or entirely to higher growth before the LBO.) ${ }^{20}$ The disadvantage is that differences in annual productivity changes are estimated less precisely than differences in five-year growth rates. This is partly due to the

20 Further analysis along the lines of Table 5 cast doubt on this possibility, however. When we replaced the single (1981-86) LBO dummy by two LBO dummies -- "early" (1981-83) and "late" (1984-86) -- their respective coefficients were .033 and .021 , i.e. "early" LBOs were associated with higher productivity increases, although the difference in coefficients was not significant. 
fact that the fraction of plants involved in an LBO during a single year is smaller than the fraction (ever) involved during a six-year period. Our estimates of $L B O$ vs. non-LBO mean productivity differences are obtained by regressing the residual on an LBO dumny variable; the latter may be viewed as a binomially distributed random variable, equal to 1 ( $1 \mathrm{f}$ and only if an LBO occurs) with probability $\theta$, and equal to 0 with probability 1- $\theta$. The variance of the LBO dummy is $N \theta(1-\theta)$, which is an increasing function of $\theta$ (provided that $\theta<.5$, which is true in our data). Since the variance of the coefficient on the LBO dumm is inversely related to the variance of the LBO dummy, hence inversely related to $\theta$, the coefficient on the five-year LBO dumny is estimated more precisely than the coefficients on annual LBO dummies.

Mean productivity differences $\left(\bar{e}_{\text {LBO }}-\bar{e}_{\text {NON-LBO }}\right)$ and $\left(\bar{e}_{\text {MBO }}-\bar{e}_{\text {NON-MBO}}\right)$, by year relative to the year of the LBO or MBO, are reported in Table 6 and plotted in Charts 2 and 3 . We don't report differences beyond two years after the deal since very few plants are observed for more than two years after the deal ( $\theta$ declines sharply as $k$ increases). 21 The results in the first column indicate that plants involved in LBOs in year $t$ tended to have above-average productivity in every year from $t-13$ to $t+2$. But the relative productivity of LBO plants appears to have declined in the years prior to the LBO, and then increased sharply beginning at the time of the LBO. The average value of the difference in three periods is as follows:

21 Recall that plants are observed only through 1986, and the LBOs all occurred during 1981-86, most of them in the last 3 years. 
Period

I $(t-13)$ to $(t-7)$

II $(t-6)$ to $(t-1)$

III $t$ to $(t+2)$
Average value of

$\left(\bar{e}_{\text {LBO }}-\bar{e}_{\text {NON-LBO }}\right)$

2.0

1.2

2.7

In year $t+1$, the productivity difference is larger (and more significant) than it was in any previous year, although it declines (and is only marginally significant) in year $t+2$. The average productivity difference increases from 1.2 in the 2 years before the $L B O$ to 2.9 in the 2 years after the $L B O$.

In many respects, the pattern of productivity differences for MBOs is similar (although more pronounced) to the pattern for LBOs: the average value of $\left(\bar{e}_{\text {MBO }}-\bar{e}_{\text {NON-MBO}}\right)$ is 2.3 in period $I, 1.2$ in period II, and 5.9 in period III. Relative productivity of MBO plants was as high as 3.6 in $t-11$ but fell to essentially zero 6 to 4 years before the MBO. But the relative productivity of MBO plants apparently began to increase about three years before the MBO, and reached a record (until that point) high of 4.9 in year $t-1$. Despite this, the average productivity residual increased from 3.6 in the two years before to 7.5 in the two years after the MBO. The difference between the productivity increases associated with MBOs and LBOs using annual measures is even greater than that suggested by the five-year growth-rate results.

While the data clearly indicate buyouts tend to be followed by substantial increases in productivity, the causal interpretation of this correlation is open to question. In particular, one could argue (1) that there is exogenous variation in plants' expected increase in relative productivity; (2) that plants with large expected productivity increases (about which management may have private information) are most likely to 
be acquired via an LBO; and (3) that actual productivity growth is a noisy indicator of expected productivity growth. Smith (1989) considered arguments of this sort, and although she could not rule them out entirely, she presented evidence which suggested that they could not account for the post-buyout improvement in performance. First, no improvement in performance was found following 24 unsuccessful MBO proposals. Second, the improvement in performance following nondefensive MBOs and/or MBOs initiated by current management -- the most likely context for potential gains from trading on inside information via an $M B O$-- tended to be no greater than the improvement following other MBOs.

In our 1987 paper we estimated differences in mean productivity between plants involved in ownership changes (of all types) and plants not so involved, which we denote by $\left(\bar{e}_{O C}-\bar{e}_{\text {NON-OC }}\right)$. Those differences (calculated from $t-7$ to $t+7$ ) also exhibited a $U$-shaped time-path (whose turning point approximately coincided with the date of ownership change), but the position of the path was "shifted down": the productivity differences were negative in every year. As noted earlier, due to data limitations we can't really identify the LBO and MBO productivity trajectories past year $t+2$, but if we assumed them to be similar in shape to the $\left(\bar{e}_{O C}-\bar{e}_{N O N-O C}\right)$ trajectory for the years after $t+2$ (as they are for the years before and including $t+2$ ), we could infer that they continue to rise (or at least do not fall) after $t+2$.

IV. Decomposition of productivity changes into output and input changes The preceding evidence is quite consistent with the hypothesis that plants involved in LBOs -- and especially in MBOs -- experience higher rates of productivity growth than other plants in the same industry, and that the relative productivity increases occur at or near the time of the 
buyout. By definition, differences in productivity growth rates are due to differences in output growth rates, differences in input (capital, labor, and materials) growth rates, or both. In this section we provide a decomposition of the productivity changes into output and input changes.

The first column of Table 7 indicates that LBO (and particularly MBO) plants had higher growth rates of output during 1981-86 than non-LBO plants, but the differences aren't statistically significant. We can't reject the hypothesis that buyout plants had a constant market share during this period. In light of our productivity findings, this implies that buyout plants had lower growth rates of total input. The last three columns of the table indicate that the growth rates of labor, and particularly of capital (but not of materials), were significantly lower in the case of all LBOs. Among the subset of MBO plants, these differences in growth rates were also negative, but smaller and not significant.

As discussed earlier, the problem with interpreting the 5-year growth rate differences is that they don't reveal the precise timing of movements relative to the date of the buyout. To shed light on this question, we present in Table 8 differences in annual growth rates of output and inputs in year $t+k(k=-2,1,0,1,2)$ between plants involved and not involved in $\mathrm{LBOs}$ in year $t$. As noted above, due to the relatively small number of LBOs in any given year the standard errors on the differences are fairly large. The differences in capital and labor growth are negative in every year; these differences are significant only in the years before the LBO (years $t-2, t-1$, and $t$ ). In the case of all three inputs, the average difference in growth rates is lower (more negative) in the 3 years before the LBO than it is in the 2 years after. 
Thus, although the relative (to industry mean) amount of inputs utilized in LBO plants is lower several years after the buyout than it was several years before, input use was declining prior to the buyout, and at a faster rate than it was after the buyout.

The Census establishment data enable us to examine the behavior of labor-related variables other than total labor input. Table 9 reports differences between LBO plants and non-LBO plants in the growth rates of the wage bill B (total labor income generated), employment E, and the annual wage rate $W_{A} \equiv B / E$, separately for nonproduction and production workers, by year relative to the year of the LBO. Nonproduction workers account for about 30 percent of total employment in manufacturing establishments. It also reports differences in growth rates of the hourly wage rate $W_{H}$ and of annual hours of work per employee $H$ for production workers only (hours of nonproduction workers are not reported in the survey). These growth rates are interrelated since (using dot superscripts to denote growth rates):

$$
\begin{aligned}
\dot{B} & =\dot{E}+\dot{W}_{A} \\
& =\dot{E}+\dot{W}_{H}+\dot{H}
\end{aligned}
$$

The first column of the table reveals that in the three years before the $\mathrm{LBO}$, the wage bill of nonproduction workers is growing at about the same rate in $L B O$ and non-LBO plants, but in the two years after the LBO, this wage bill is growing much more slowly in LBO plants: the average annual rate of relative decline is 5.3 percent. The decline is particularly pronounced ( 7.2 percent) in year +2 . In contrast, the wage bill of production workers is slightly increasing in relative terms after the LBO, so there is a sharp drop in the growth of the ratio of the 
nonproduction to production wage bill. Consequently, LBOs might be interpreted as non-neutral or biased organizational innovations that are relatively production-labor using and nonproduction-labor saving.

The post-LBO decline in the nonproduction wage bill is almost equally due to reductions in nonproduction employment and annual wages (2.7 and 2.6 percent, respectively). Both the employment and especially the annual wage of nonproduction relative to production workers declines following LBOs. This suggests that LBOs reduce the demand for nonproduction workers relative to the demand for production workers. Because the annual wage of nonproduction employees tends to be substantially (about 53 percent) higher than that of production employees, the decline in their relative wage would appear to reduce inequality of wages within LBO plants.

The growth in the annual wage rate of production workers is significantly higher in LBO plants than in other plants in the same industry in the two years following the LBO. About two-thirds of this difference is attributable to hourly wage rates, and one-third to annual hours. After an LBO, production-worker employment declines (in relative terms) at an average annual rate of 0.9 percent, but total hours of production workers (E - H) decline more slowly than they did during the three years before the LBO.

To summarize the preceding observations:

1) Total hours worked by production workers decline more slowly after the LBO than before the LBO.

2) Hourly and (especially) annual wage rates of production workers increase after a buyout.

3) Both employment and annual wages of nonproduction workers decline sharply after a buyout. 
It is interesting to consider the increase in production-worker wages and the decrease in relative employment of nonproduction workers in post-LBO plants from the perspective of "efficiency wage" theory. 22 A premise of that theory is that the firm has two alternative means of inducing (production) workers to expend effort (which it is costly for the firm to monitor): the "carrot" of high wages (paying a wage premium) and the "stick" of intensive supervision (a high ratio of nonproduction to production workers). Our evidence is consistent with the view that in the course of the pre- to post-LBO transition management increases the use of the carrot and reduces the use of the stick.

\section{Plant closings}

The differences between buyout and non-buyout plants in productivity, output and inputs reported in Tables 5 through 9 were all based on the subset of "surviving" plants, i.e. plants present in the LRD in 1981 that had not closed by some subsequent year. Calculations for any particular year during the period 1981-86 were based on all plants ever in the sample that had not closed prior to that year. Because the plants that close are likely to be a nonrandom sample (in terms of their productivity, for example) of all plants, estimates based on the "censored" sample of surviving establishments may be biased. Unfortunately, nonrandom censoring of observations in a longitudinal context poses extremely difficult methodological problems $;^{23}$ our objective here is simply to

22 See Bartel and Lichtenberg (1988) for a recent discussion of efficiency-wage theory.

23 See Pakes and Ericson (1989) for a recent, very sophisticated attempt to address some of these problems. 
document the extent of plant failure (closing) and to try to assess the direction of bias in our comparisons of buyout and nonbuyout plants.

First, we provide some evidence concerning the relationship between productivity and plant closing. Table 10 shows differences in the mean productivity residual in each of the years 1972-81 between plants that closed and didn't close in 1981. The productivity of plants closing in 1981 was significantly lower than that of other plants in each of the ten years prior to closing, and the productivity gap was widening as the closing date approached. In addition to having negative and declining levels of relative productivity, columns 2 and 3 of the table show that plants destined to close in the future have negative and generally declining relative rates of output and employment growth.

Since Table 10 shows that the probability of (future) plant closing is inversely related to productivity, and Table 6 revealed that LBO (and especially MBO) plants exhibit above-average productivity around the date of (especially after) the buyout, one would expect there to be a lower incidence of plant closings among LBO (and especially MBO) plants than among non-buyout plants.

Table 11 presents rates of plant closing in each of the years 1981-86 for six cohorts of LBO and MBO plants and for all plants in our extract of the LRD. These are conditional rates of closing, i.e. relative frequencies of closing in year $t$ among plants that have not closed prior to year $t$. The top panel of the table shows closing rates among plants involved in all LBOs (both MBOs and other LBOs). There are a total of 21 year-specific closing rates for the 6 LBO cohorts, and 11 of these are smaller, and 10 are larger, than the rates for all sample plants in the corresponding year. These data therefore give the 
impression that plants previously involved in LBOs are neither more nor less likely to close than other plants. ${ }^{24}$ The apparent lack of a difference may be partly due to the fact that, although LBO plants are more productive, they are also somewhat smaller (mean employment 17 to 25 percent lower) than non-LBO plants, and Dunne, Roberts, and Samuelson (1987) have shown that large plants are less likely to close. In contrast, only 5 of the 21 MBO plant closing rates, shown in the bottom half of the table equal or exceed the closing rates for all sample plants in the corresponding year. The preponderance of zeroes for the 1981 and 1982 MBO cohorts may partly be an artifact of the small number of MBO plants in those cohorts ( 16 or less in each), but even among the last 4 cohorts (whose minimum initial size was 57 ), only 3 out of 10 equal or exceed their corresponding year's rate for all sample plants. Thus MBO plants appear to be appreciably less likely to close than plants not involved in LBOs. Our finding a difference for these plants but not for LBO plants in general may be due not only to the markedly higher productivity of thes's plants, but also to their greater size -- they are only 1 to 13 percen'i smaller, on average, than plants not involved in buyouts.

The iower rates of plant closing among plants involved in management buyouts suggest that estimates of differences between MBO and non-MBO plants based on the censored sample may be downward biased. Tables 5 and 6 may underestimate the productivity increase associated with management buyouts, and the estimated differences in output and input growth of MBO plants reported in Table 7 may be too negative. 
VI. $\quad$ \& \& $D$ investment

We examined above the relationship between LBOs and the growth of the capital stock, which is closely related to the rate of net investment in plant and equipment. In this section we investigate the relationship between LBOs and investment in research and development. There is considerable evidence that $R \& D$ investment has a significant positive impact on long-run productivity growth. ${ }^{25}$ Due to data limitations, we were able above to analyze only the short-run (within two-year) "effect" of buyouts on TFP. Analysis of the link between buyouts and R\&D investment may provide at least indirect evidence concerning the implications of buyouts for long-run productivity growth. 26

The LRD does not contain any information about investment in R\&D in manufacturing establishments. Even if it did, such information would not be very meaningful. Lichtenberg and Siegel (1989a, p. 8) reported that 47 percent of personnel engaged in R\&D are employed in "auxiliary establishments" (including central administrative offices and R\&D laboratories) rather than in manufacturing establishments. $R \& D$ is a relatively centralized function within companies, and since the output of $R \& D$ is a relatively "public good" (easily diffused across the company's establishments), it is the amount of R\&D conducted in the entire company, rather than in specific establishments, that determines their productivity. This is presumably the reason why the government's official survey

25 See Lichtenberg and Siegel (1989b) for an econometric analysis of this impact based on Census microdata.

26 From another perspective, by examining the effects of IBOs on R\&D as well as on (short-run) TFP, we are assessing their impact on dynamic as well as static (technical) efficiency. 
of industrial R\&D activity -- the NSF/Census RD-1 survey -- is a firmlevel survey.

We used data from the RD-1 survey to assess the impact of LBOs on $R \& D$ investment. Our strategy is to compare the change in average R\&D intensity (one measure of which is the ratio of $R \& D$ investment to sales) of firms involved in LBOs ("LBO firms") to that of all firms. We have two reasons for choosing R\&D-intensity (rather than, for example, real R\&D expenditure) as the measure to be examined. First, a reduced-form relationship between TFP growth and R\&D-intensity can be formally derived from a production function which includes as an argument the stock of "knowledge capital," and such a relationship has been estimated in numerous studies. 27 Second, LBOs are frequently followed by the divestiture of divisions of the acquired company; such divestitures would tend to artificially depress the change in real $R \& D$, but not the change in R\&D-intensity (unless the most R\&D-intensive divisions were most likely to be divested.)

Because the RD- 1 data are at the firm level, we will include only LBOs of entire firms, and not of divisions of firms, in our set of "LBO firms." Recall from Table 3 that there were 80 major LBOs of entire firms involving companies observed in the Census data and that these accounted for about 70 percent of the aggregate value of LBOs. 43 out of these 80 companies were included in the sample of $\mathrm{RD}-1$ survey firms in each of the years 1978-86. These 43 companies comprise our set of "LBO firms."

27 See, e.g., Lichtenberg and Siegel (1989b). 
Sample mean values of R\&D-intensity in the years 1978-86 for both the 43 LBO firms and for all R\&D performers are presented in Table 12. Two alternative measures of $R \& D$-intensity are used: the ratio of $R \& D$ expenditure to sales (RDINT1), and the ratio of the number of full-timeequivalent R\&D scientists and engineers to total company employment (RDINT2). The mean values for LBO firms of both these measures tended to increase over this 9-year period, and were never higher than they were in the last year, by which all the buyouts were completed. The mean values of RDINTI and RDINT2 for LBO firms were respectively 50 percent and 21 percent greater in 1986 than they had been in 1978. The average R\&D intensity of all $\mathrm{R} \& \mathrm{D}$-performers in the $\mathrm{RD}-1$ sample was also increasing significantly during the period. ${ }^{28}$ The relative R\&D intensity of LBO firms (shown in the last column) therefore increased less than the absolute R\&D intensity, but it increased nevertheless, particularly in the last 3 years, during which most of the LBOs occurred.

The data in Table 12 cast doubt on the hypothesis that LBOs are associated with reductions in the propensity to perform R\&D. Another way of examining the data, which accounts more closely for the timing of the LBOs, also yields results inconsistent with the hypothesis. For each of the years 1981-86, we identified the set of firms that were involved in an LBO either in that year or in a previous year. For both these firms and for all firms we then calculated the proportion of firms which had increased their $R \& D$-intensity since the previous year. The results are

28 To an important extent, this increase -- even in the "company-financed" component -- may be attributable to the large U.S. military buildup during the period. See Lichtenberg (1988) for discussion of this point. 
presented in Table 13. The proportion for firms involved in current or past LBOs is never lower than the proportion for all firms, and is equal in only one year.

There have been at least two large-scale studies of the effect of changes in ownership (mergers and acquisitions) in general on R\&D investment: Hall (1988) and Lichtenberg-Siegel (1989a). Both found essentially no difference in the growth of $R \& D$ between firms involved and not involved in ownership change. We are aware of only one very limited attempt to assess the effects of LBOs in particular on R\&D; it is described in a Feb. 1, 1989 memorandum by the National Science Foundation (NSF) prepared in response to a request from the Subcomittee on Telecommunications and Finance of the House Committee on Energy and Commerce. NSF identified 8 companies among the top 200 R\&D performers involved in "LBOs or other restructurings," and determined that these companies reduced their R\&D expenditure by 12.8 percent from 1986 to 1987 . In contrast, other top-200 companies not involved in mergers, LBOs or other restructurings increased their R\&D spending by 5.4 percent.

NSF granted to us access to their list of 8 companies involved in "LBOs or other restructurings"; only one of these companies appeared on our presumably comprehensive list of major LBOs. The rest of the companies were evidently involved in "other restructurings" such as stock repurchases. There are at least 3 reasons, therefore, why the figures calculated by NSF might be regarded as very unreliable estimates of the effects of LBOs per se on R\&D investment: (1) only one of the eight companies was actually involved in an LBO; (2) NSF calculated the change in R\&D in only a single year; and (3) they evaluated the change in the level of $R \& D$, rather than in $R \& D$ intensity, which is misleading if the 
companies are divesting divisions -- a frequent concomitant of restructuring.

\section{Summary and conclusions}

In this paper we have investigated the effects of leveraged buyouts on productivity and related aspects of firm behavior using large longitudinal establishment- and firm-level Census Bureau data sets linked to a list of LBOs compiled from public data sources. About 5 percent, or 1100 , of the roughly 20,000 relatively large manufacturing establishments represented in our extract from the LRD file were involved in an LBO during the period 1981-86. This is about one-fourth the fraction involved in all types of mergers and acquisitions.

We found that plants involved in LBOs during 1981-86 had significantly (about 14 percent) higher rates of productivity growth over that five-year span than other plants in the same industry. The productivity impact of LBOs is much larger than previous estimates of the productivity impact of all mergers and acquisitions. Among MBOs -- the subset of LBOs in which the acquiror includes the managers of the acquired unit -- the productivity growth differential was even larger -- about 20 percent.

Two factors which may contribute to the relative productivity increase among LBO plants are: (1) increased intensity of effort by labor, and more generally, increased utilization of all employed inputs, due to increased sensitivity of their financial rewards (and penalties) to their performance; and (2) reduction in the proportion of resources misallocated to inefficient activities, due to curtailment of "free cash flow" and to more intensive monitoring of managers by investors.

Our previous research suggests that a significant fraction of the productivity gains associated with changes in corporate control are due 
to reductions in central-office overhead. Since data on central offices were unfortunately not available for this investigation, the estimated productivity gains may substantially understate the true gains.

The estimates suggest that plants involved in LBOs had above-average levels of productivity 10 to 12 years prior to the buyout, but experienced gradual declines in subsequent years until they were just above average on the eve of the buyout. In the year of or following the buyout, the relative productivity of these plants increases sharply to a level higher than that ever previously observed. The productivity of plants involved in MBOs appears to increase several years before the buyout, although their productivity advantage widens considerably after the buyout. Plants involved in "garden-variety" ownership changes have productivity significantly below average immediately prior to the transaction; plants involved in LBOs are no worse than average, and those involved in $\mathrm{MBO}$ s are better than average.

The difference in 1981-86 productivity growth rates between LBO plants and non-LBO plants is mostly due to lower input growth, rather than higher output growth, of the former. Plants involved in LBOs during 1981-86 tended to employ less capital and labor, relative to the industry average, in 1986 than they did in 1981. But the relative quantities of capital and labor employed in LBO plants were declining for several years before the buyout as well as for several years after, and the rate of decline was smaller (and less significant) after. LBOs are thus associated with a reduction in the rate of (relative) downsizing.

LBOs tend to be preceded or followed by significant and differential changes in the wages, hours, and employment of production and nonproduction employees. Total hours worked by production workers 
decline more slowly after than before the LBO. Their hourly and (especially) annual wage rates increase after the buyout. In stark contrast, both the employment and wages of nonproduction workers decline sharply following an LBO. These findings suggest that LBOs are associated with reductions in intraplant wage dispersion and also with increased reliance on wage incentives, and reduced reliance on monitoring by supervisors, to elicit effort on the part of production workers. LBOs appear to be production-labor-using, nonproduction-labor-saving, organizational innovations .

The results summarized above are based on the censored sample of surviving establishments, i.e. plants that close are excluded from the productivity, output and input growth calculations. (About 12 percent of the plants present in 1981 are known to have closed within the next five years.) Plants involved in management buyouts (but not in LBOs general1y) were less likely to subsequently close than other plants, as one would expect given their relative productivity and the inverse relationship between productivity and the likelihood of plant closing. Consequently, censoring of failing establishments may result in downwardly biased estimates of differences between $M B O$ and non-MBO plants in productivity, output and input growth.

The final issue we investigated empirically was the effect of LBOs on R\&D-intensity, which has previously been shown to be a significant determinant of the long-run rate of productivity growth. Because R\&D is generally a firm- as opposed to establishment-level function, analysis of this issue was based on a distinct set of data, the RD-1 survey panel. We found that the average R\&D-intensity of a subset of 43 firms involved in (complete-firm) LBOs increased substantially during the period 
1978-86. The R\&D-intensity of all firms was also generally rising during this period, but at a rate no faster than that of the R\&D-intensity of LBO firms. These findings are not at all consistent with the hypothesis that $L B O s$ are associated with reductions in the propensity of firms to invest in R\&D. 


\section{REFERENCES}

Abbott III, Thomas A. (1988), "Price Dispersion in U.S. Manufacturing," Center for Economic Studies Working Paper, U.S. Bureau of the Census.

Bartel, Ann, and Lichtenberg, Frank (1988), "Technical Change, Learning, and Wages," NBER Working Paper No. 2732, October.

Dunne, Timothy, Roberts, Mark, and Samuelson, Larry (1987), "The Impact of Plant Failure on Employment Growth in the U.S. Manufacturing Sector," mimeo, Pennsylvania State University.

Hall, Bronwyn (1988), "The Effect of Takeover Activity on Corporate Research and Development," in Corporate Takeovers: Causes and Consequences, Alan Auerbach (ed.) (Chicago: Univ. of Chicago Press), 9-25.

Jensen, Michael (1986), "The Agency Costs of Free Cash Flow: Corporate Finance and Takeovers," American Economic Review 76, May.

(1989), "The Effect of LBOs and Corporate Debt on the Economy,".

Kaplan, Steven (1988), "Sources of Value in Management Buyouts," unpub. doctoral thesis, Harvard Business School, October.

Lichtenberg, Frank (1988), "The Private R\&D Investment Response to Federal Design and Technical Competitions," American Economic Revier 78 , June, 550-559.

and Siegel, Donald (1987), "Productivity and Changes in Ownership of Manufacturing Plants," Brookings Papers on Economic Activity, 643-673.

(1989a), "The Effect of Takeovers on the Employment and Wages of Central-Office and Other Personnel," NBER Working Paper No. 2895 March.

(1989b), "Using Linked Census R\&D-LRD Data to Analyze the Effect of R\&D Investment on Total Factor Productivity Growth," Bureau of the Census, Center for Economic Studies Discussion Paper CES 89-2, January.

Maddala, G.S. (1979), "A Note on the Form of the Production Function and Productivity," in National Research Council, Measurement and Interpretation of Productivity (Washington: National Academy of Sciences), 309-317.

McGuckin, Rohert H., and Andrews, Stephen H. (1988), "The Performance of Lines of Business Purchased in Conglomerate Acquisitions," presente. at the American Economic Association meetings in Chicago, Dec. 25-30, 1987. 
McGuckin, Robert H., and Pascoe, George A. (1988), "The Longitudinal Research Database: Status and Research Possibilities," Survey of Current Business, November, 30-37.

Murphy, Kevin M., and Topel, Robert H. (1985), "Estimation and Inference in Two-Step Econometric Models," Journal of Business and Economic Statistics 3, October, 370-379.

Neter, John, Wasserman, William, and Kutner, Michael H. (1985), Applied Linear Statistical Models 2nd. ed. (Homewood: Irwin)

Pakes, Ariel, and Ericson, Richard (1989), "Empirical Implications of Alternative Models of Firm Dynamics," NBER Working Paper No. 2893, March.

Roach, Stephen S. (1989), "Living With Corporate Debt," Journal of Applied Corporate Finance 2, Spring, 19-29.

Smith, Abbie (1989), "Corporate Ownership Structure and Performance: The Case of Management Buyouts," unpub. paper, Univ. of Chicago, January.

Solow, Robert M. (1957), "Technical Change and the Aggregate Production Function," Review of Economics and Statistics 39, August, 214-231.

U.S. Bureau of Labor Statistics (1988), "Multifactor Productivity Measures, 1987," USDL 88-478, Sept. 30 .

U.S. National Science Foundation (1989), "An Assessment of the Impact of Recent Leveraged Buyouts and Other Restructurings on Industrial Research and Development Expenditures," February 1.

Forbes (1989), "Born-Again Stocks," March 20, 210-211.

Mergers and Acquisitions, various issues. 
Table 1

Aggregate Value and Number of

Leveraged Buyouts and Mergers and Acquisitions, 1981-1986

\begin{tabular}{|c|c|c|c|c|c|c|}
\hline \multirow[b]{2}{*}{ Year } & \multicolumn{3}{|c|}{ Leveraged Buyouts } & \multicolumn{3}{|c|}{ Mergers and Acquisitions } \\
\hline & $\begin{array}{l}\text { Total } \\
\text { Value }\end{array}$ & $\begin{array}{l}\text { Number } \\
\text { of deals }\end{array}$ & $\begin{array}{l}\text { Average } \\
\text { Value }\end{array}$ & $\begin{array}{l}\text { Total } \\
\text { Value }\end{array}$ & $\begin{array}{l}\text { Number } \\
\text { of deals }\end{array}$ & $\begin{array}{l}\text { Average } \\
\text { Value }\end{array}$ \\
\hline \multicolumn{7}{|c|}{ Deals of all sizes } \\
\hline $\begin{array}{l}1981 \\
1982 \\
1983 \\
1984 \\
1985 \\
1986\end{array}$ & $\begin{array}{r}\$ 3093 \\
3452 \\
4520 \\
18810 \\
18030 \\
46620\end{array}$ & $\begin{array}{r}99 \\
164 \\
231 \\
253 \\
254 \\
333\end{array}$ & $\begin{array}{r}\$ 31.2 \\
21.0 \\
19.6 \\
74.3 \\
71.0 \\
140.0\end{array}$ & $\begin{array}{r}\$ 82600 \\
53700 \\
73000 \\
122300 \\
179700 \\
173100\end{array}$ & $\begin{array}{l}2395 \\
2346 \\
2533 \\
2543 \\
3001 \\
3336\end{array}$ & $\begin{array}{r}\$ 34.5 \\
22.9 \\
28.8 \\
48.1 \\
59.9 \\
51.9\end{array}$ \\
\hline \multicolumn{7}{|c|}{ Deals of value $>\$ 35$ million } \\
\hline $\begin{array}{l}1981 \\
1982 \\
1983 \\
1984 \\
1985 \\
1986\end{array}$ & $\begin{array}{r}3136 \\
3422 \\
3853 \\
18805 \\
13036 \\
43850\end{array}$ & $\begin{array}{l}17 \\
21 \\
30 \\
53 \\
44 \\
79\end{array}$ & $\begin{array}{l}184.5 \\
162.9 \\
128.4 \\
354.8 \\
296.3 \\
555.1\end{array}$ & $\begin{array}{r}71128 \\
47836 \\
63532 \\
121274 \\
186009 \\
198190\end{array}$ & $\begin{array}{l}235 \\
246 \\
306 \\
403 \\
505 \\
768\end{array}$ & $\begin{array}{l}302.7 \\
194.5 \\
207.6 \\
300.9 \\
368.3 \\
258.1\end{array}$ \\
\hline \multicolumn{7}{|c|}{$\begin{array}{l}\text { Deals of all sizes: } \\
\text { LBOs: Mergers and Acquisitions } \\
\text { M\&As: W.T. Grim \& Co. } \\
\text { Deals of value }>\$ 35 \text { million: } \\
\text { Securities Industry Association data base. } \\
\text { Value figures are in millions of dollar. }\end{array}$} \\
\hline
\end{tabular}




\section{Table 2}

Value and Number of Leveraged Buyouts Involving Companies Observed in Census LRD Extract

\begin{tabular}{|c|c|c|c|c|c|c|c|c|}
\hline & \multicolumn{3}{|c|}{$\begin{array}{l}\text { Leveraged Buyouts of } \\
\text { value }>\$ 35 \text { m. involving } \\
\text { companies observed in } \\
\text { Census LRD extract }\end{array}$} & \multicolumn{3}{|c|}{$\begin{array}{l}\text { All leveraged buyouts } \\
\text { of value }>\$ 35 \mathrm{~m} \text {. }\end{array}$} & \\
\hline & $\begin{array}{l}\text { (1) } \\
\text { Total } \\
\text { Value }\end{array}$ & $\begin{array}{l}\text { (2) } \\
\text { Number }\end{array}$ & $\begin{array}{l}\text { (3) } \\
\text { Average } \\
\text { Value }\end{array}$ & $\begin{array}{l}\text { (4) } \\
\text { Total } \\
\text { Value }\end{array}$ & $\begin{array}{l}\text { (5) } \\
\text { Number }\end{array}$ & $\begin{array}{l}\text { (6) } \\
\text { Average } \\
\text { Value }\end{array}$ & $\begin{array}{l}\% \text { of } \\
\text { Value } \\
(1) /(4)\end{array}$ & $\begin{array}{l}\text { \% of } \\
\text { deals } \\
(2) /(5)\end{array}$ \\
\hline 1981 & 2545.4 & 13 & 195.8 & 3136.4 & 17 & 184.5 & 81.2 & 76.5 \\
\hline 1982 & 2437.4 & 14 & 174.1 & 3421.5 & 21 & 162.9 & 71.2 & 66.7 \\
\hline 1983 & 2195.2 & 16 & 137.2 & 3852.7 & 30 & 128.4 & 57.0 & 53.3 \\
\hline 1984 & 10767.6 & 27 & 398.8 & $\left.\right|_{1} ^{18804.9}$ & 53 & 354.8 & 57.3 & 50.9 \\
\hline 1985 & 6033.6 & 24 & 251.4 & 13035.6 & 44 & 296.3 & 46.3 & 54.5 \\
\hline 1986 & 24956.5 & 37 & 674.5 & 143849.9 & 79 & 555.1 & 56.9 & 46.8 \\
\hline $\begin{array}{l}\text { total } \\
\text { period }\end{array}$ & 48935.9 & 131 & 373.6 & $\mid 86101.0$ & 244 & 352.9 & 56.8 & 53.7 \\
\hline
\end{tabular}




\section{Chart 1}

Procedure for Determining Whether or Not an LRD establishment was involved in an LBO

During a Particular year

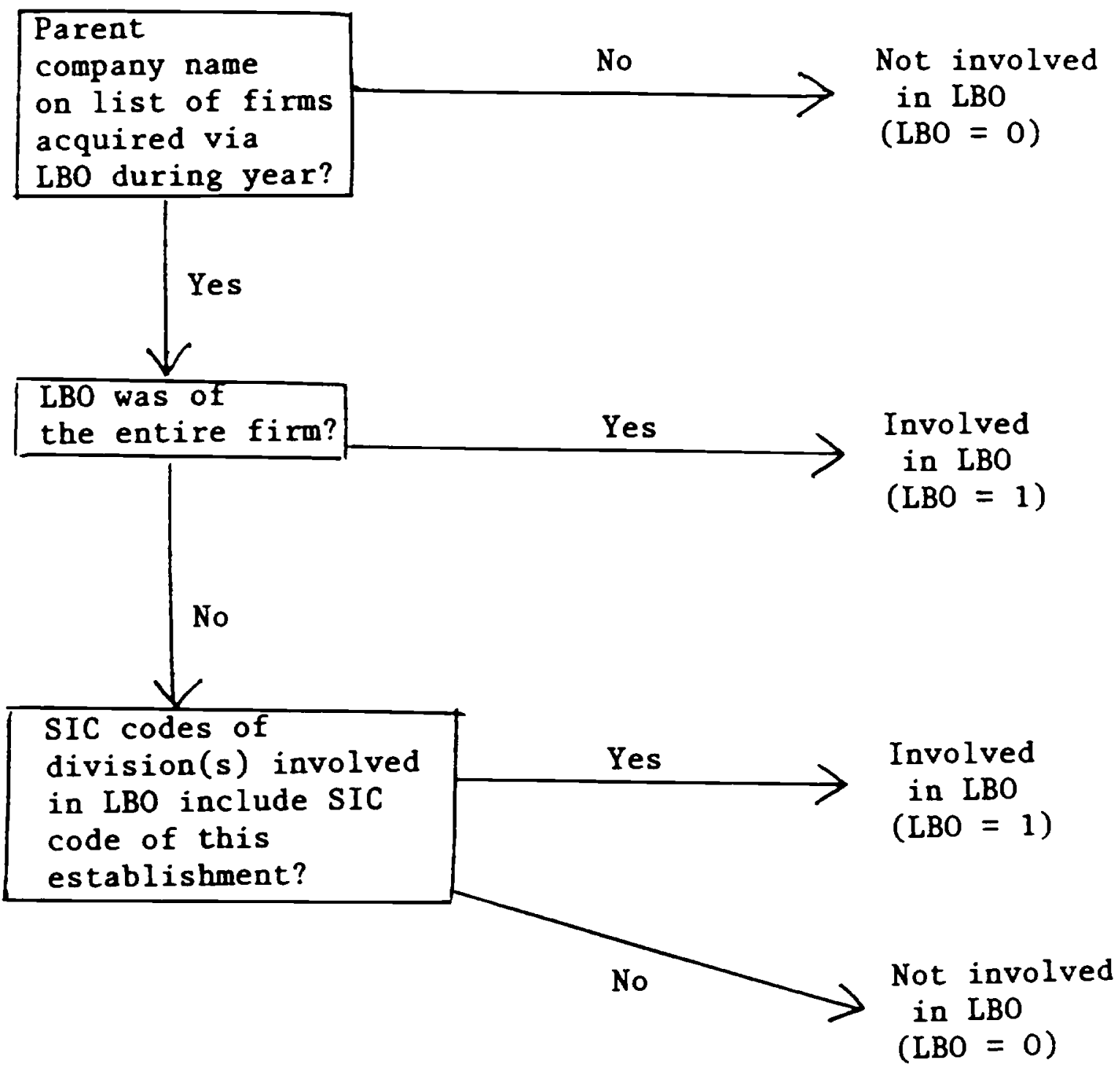


Table 3

Cumulative Value and Number of Leveraged Buyouts During 1981-86, by Selected Attributes

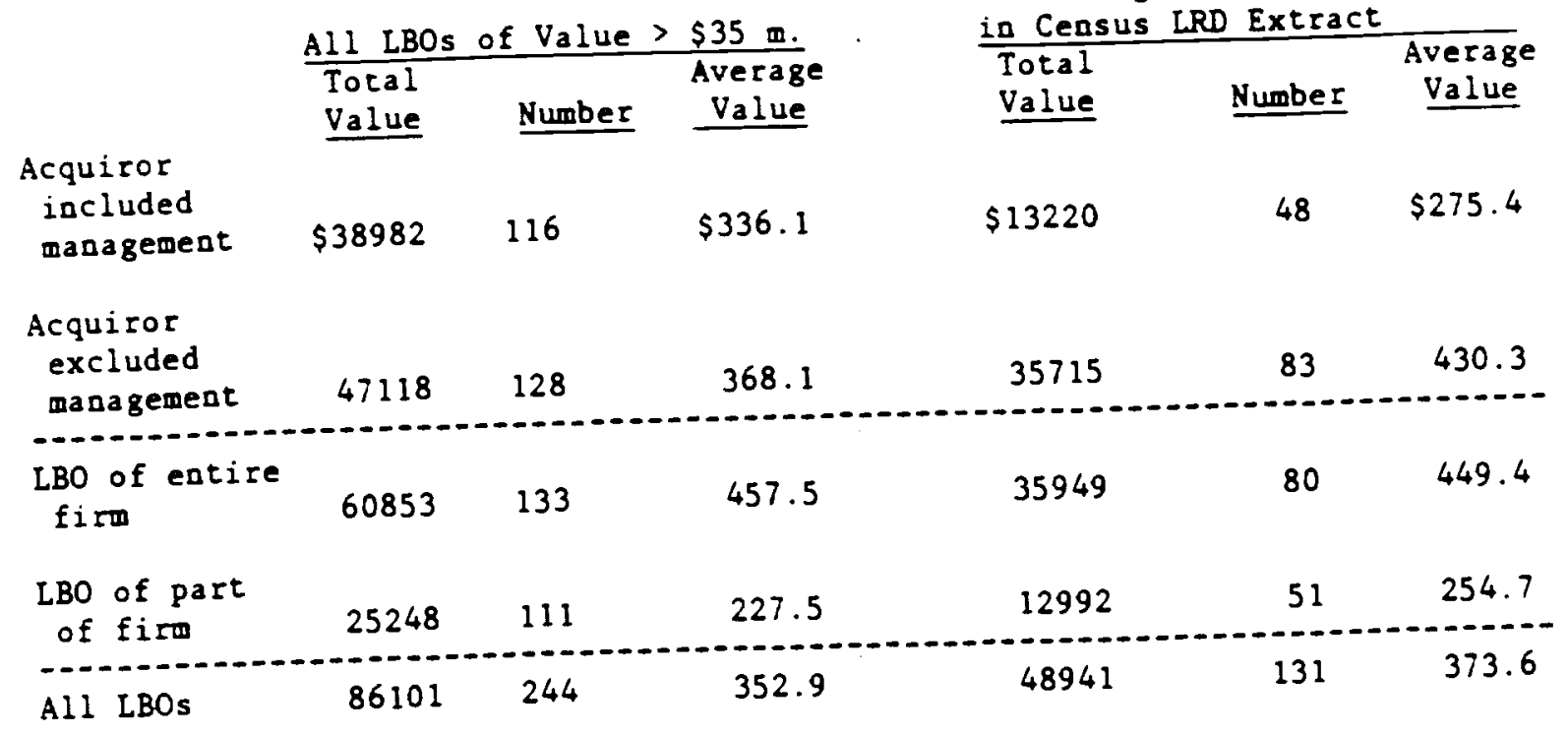

LBOs of value $>\$ 35 \mathrm{~m}$.

LBOs of value $>\$ 35$ m.

Acquiror

included

cquiror

excluded

angement

$86101 \quad 244$

LBO of part

All LBOs

8 
Table 4

Distribution of LRD establishments involved in major LBOs during 1981-86, by type of LBO

\begin{tabular}{|c|c|c|c|}
\hline & $\mathrm{MBO}$ & $\begin{array}{c}\text { Other } \\
\text { LBO }\end{array}$ & \\
\hline $\begin{array}{l}\text { FULL-FIRM LBO } \\
\text { (percent) } \\
\text { (row percent) } \\
\text { (column percent) }\end{array}$ & $\begin{array}{r}239 \\
21.1 \\
30.2 \\
59.9\end{array}$ & $\begin{array}{l}553 \\
48.9 \\
69.8 \\
75.4\end{array}$ & 791 \\
\hline \multirow[t]{2}{*}{$\begin{array}{l}\text { PARTIAL-FIRM LBO } \\
\text { (percent) } \\
\text { (row percent) } \\
\text { (column percent) }\end{array}$} & $\begin{array}{l}160 \\
14.1 \\
47.1 \\
40.1\end{array}$ & $\begin{array}{r}180 \\
15.9 \\
52.9 \\
24.6\end{array}$ & 340 \\
\hline & 399 & 733 & \\
\hline
\end{tabular}




\section{Table 5}

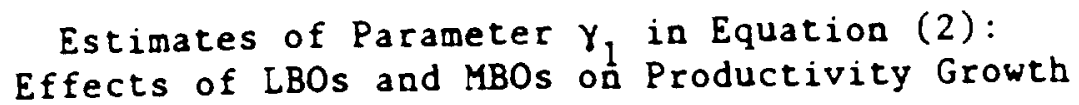

Productivity measure

Raw residual

Studentized residual
Independent variable

LBO MBO

dummy dummy

$.028 \quad .039$

(2.7) (2.3)

.100

(2.9)

.134

(2.4)

Note: $t$ - statistics in parentheses. 
Table 6

Differences Between Buyout Plants and Non-Buyout Plants in Mean Productivity Residual, by Year Relative to Year of Buyout ( $t$-statistics in parentheses)

Year

$-13$

$-12$

$-11$

$-10$

$-9$

$-8$

$-7$

$-6$

$-5$

$-4$

$-3$

$-2$

$-1$

0

1

2

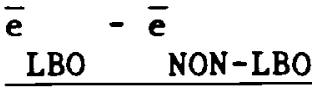

1.6

(1.3)

2.9

(2.6)

2.6

(3.0)

1.9

(2.4)

1.8

(2.4)

1.4

(2.1)

2.0

(2.9)

1.2

(1.6)

1.1

(2.1)

1.2

(1.9)

1.3

(2.2)

1. 3

(1.7)

1.1

(1.4)

2.2

(2.5)

3.5

(3.1)

2.3

(1.7) $\bar{e}-\bar{e}$

NON-MBO

1. 2

(0.6)

3.2

(1.8)

3.6

(2.3)

2.2

(1.7)

2.0

(1.6)

1.3

(1.1)

2. 3

(1.9)

$-0.1$

(0.1)

0.7

(0.8)

$-0.0$

(0.1)

1.9

(1.6)

2.2

(2.0)

4.9

(3.1)

2. 7

(1.7)

7.2

(3.2)

7.7

(3.0) 


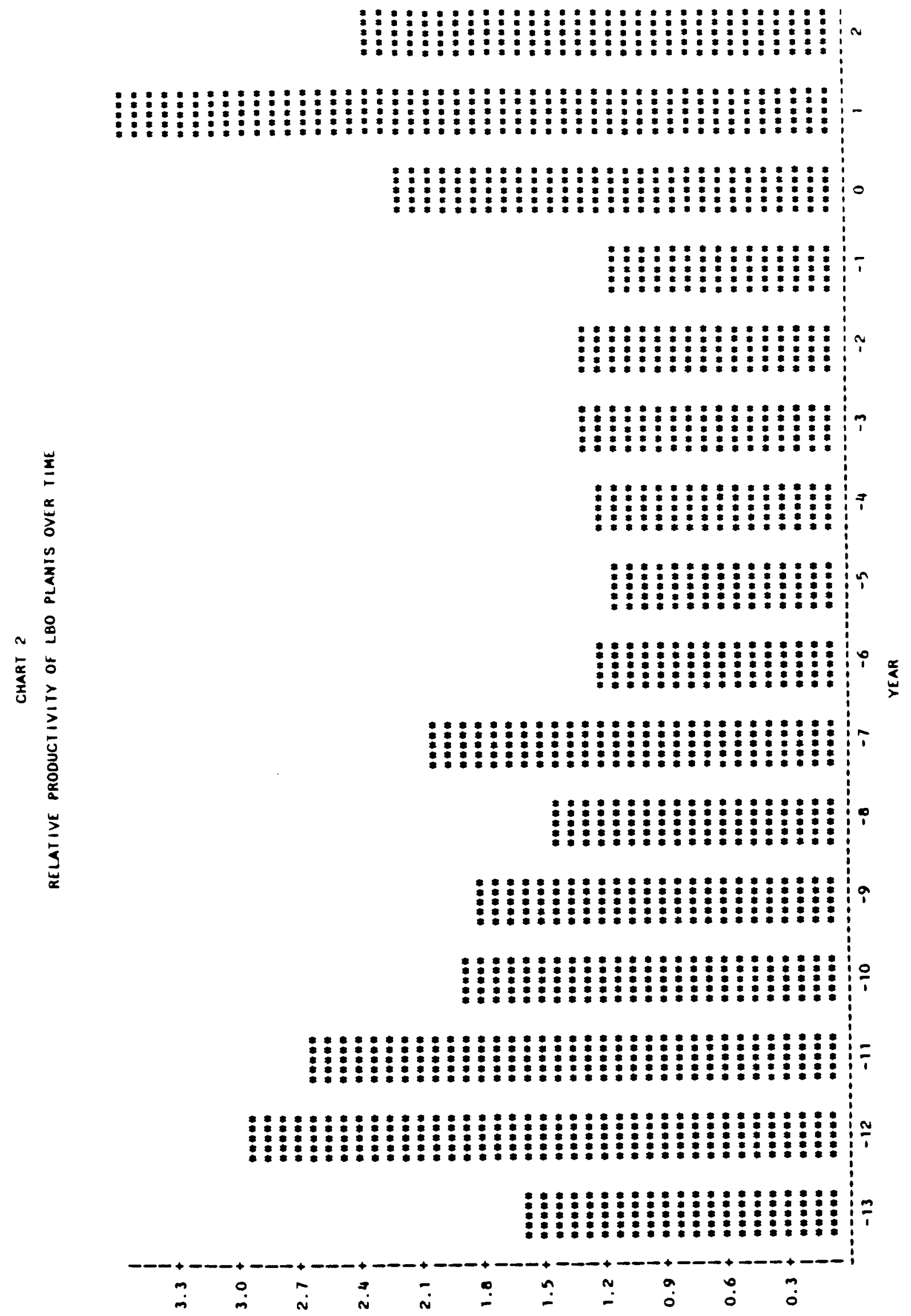




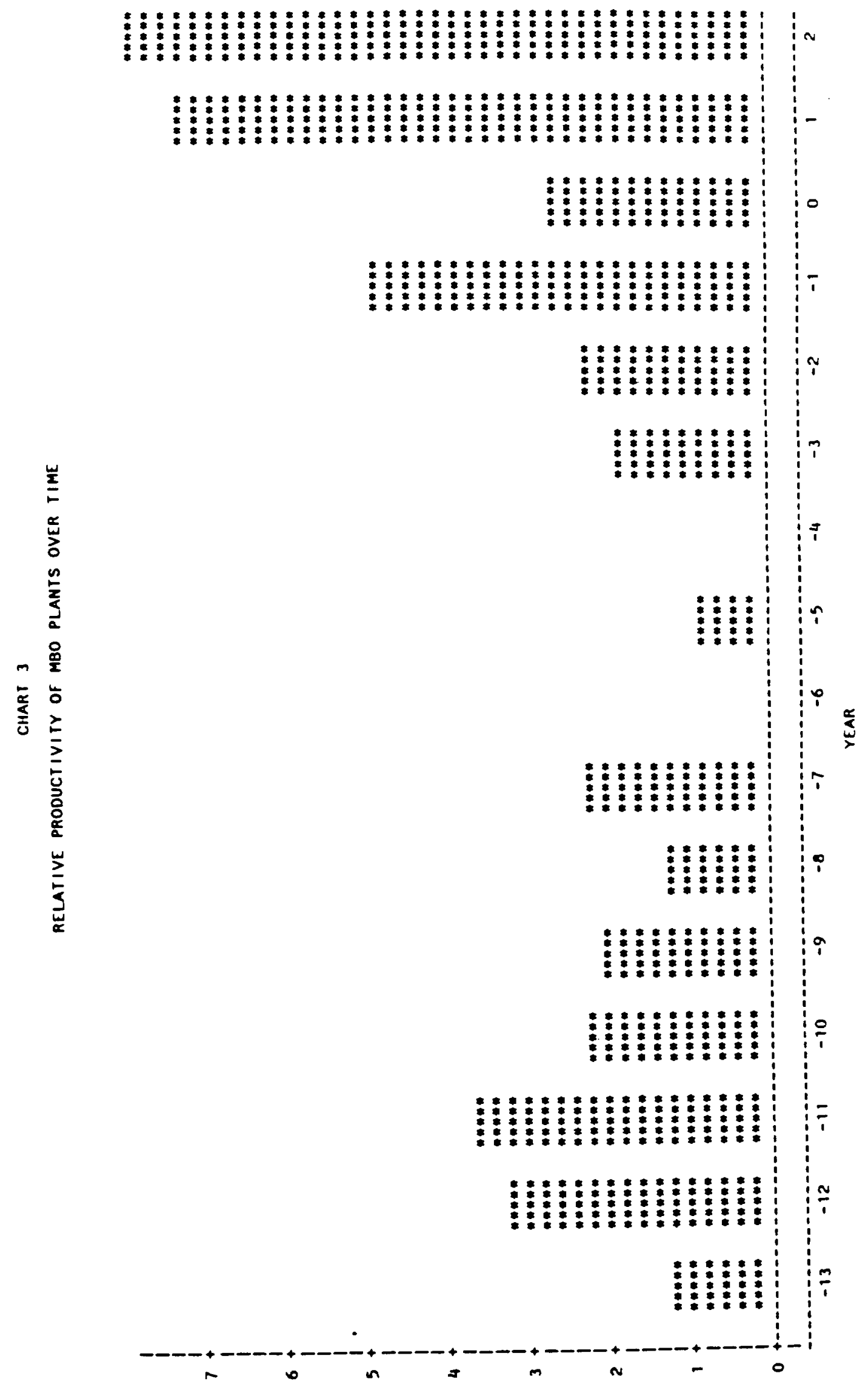


Table 7

Differences Between Buyout and Non-Buyout Plants in Mean Cumulative 1981-86 Growth Rates of Output and Inputs ( $t$-statistics in parentheses)

\begin{tabular}{|c|c|c|c|c|}
\hline & Output & Capital & Labor & Materials \\
\hline LBO plants & $\begin{array}{c}0.7 \\
(0.4)\end{array}$ & $\begin{array}{l}-6.4 \\
(3.9)\end{array}$ & $\begin{array}{l}-3.2 \\
(1.8)\end{array}$ & $\begin{array}{c}0.2 \\
(0.1)\end{array}$ \\
\hline MBO plants & $\begin{array}{c}2.5 \\
(0.7)\end{array}$ & $\begin{array}{l}-2.9 \\
(1.1)\end{array}$ & $\begin{array}{l}-1.4 \\
(0.5)\end{array}$ & $\begin{array}{l}-0.5 \\
(0.1)\end{array}$ \\
\hline
\end{tabular}

NOTE: Each of the estimates reported above is an estimate of the coefficient $\alpha_{1}$ in a regression of the form.

$\ln 286_{i}=\alpha_{0}+\alpha_{1}$ B08186 $_{i}+\alpha_{2} \ln 281_{i}+\gamma_{j}+v_{i}$ where 286 and 281 denote output, capital, labor, or materials in 1986 and 1981, respectively; B08186 equals 1 if the plant was even involved in an LBO (or MBO) during 1981-86, and otherwise equals zero; $Y_{j}$ represents a complete set of industry dummies; and the subscript $i$ is the plant index. 
Table 8

Differences Betwen LBO plants and Non-LBO Plants in Mean Growth Rates (in percent) of Output and Inputs, by year relative to year of $L B O$

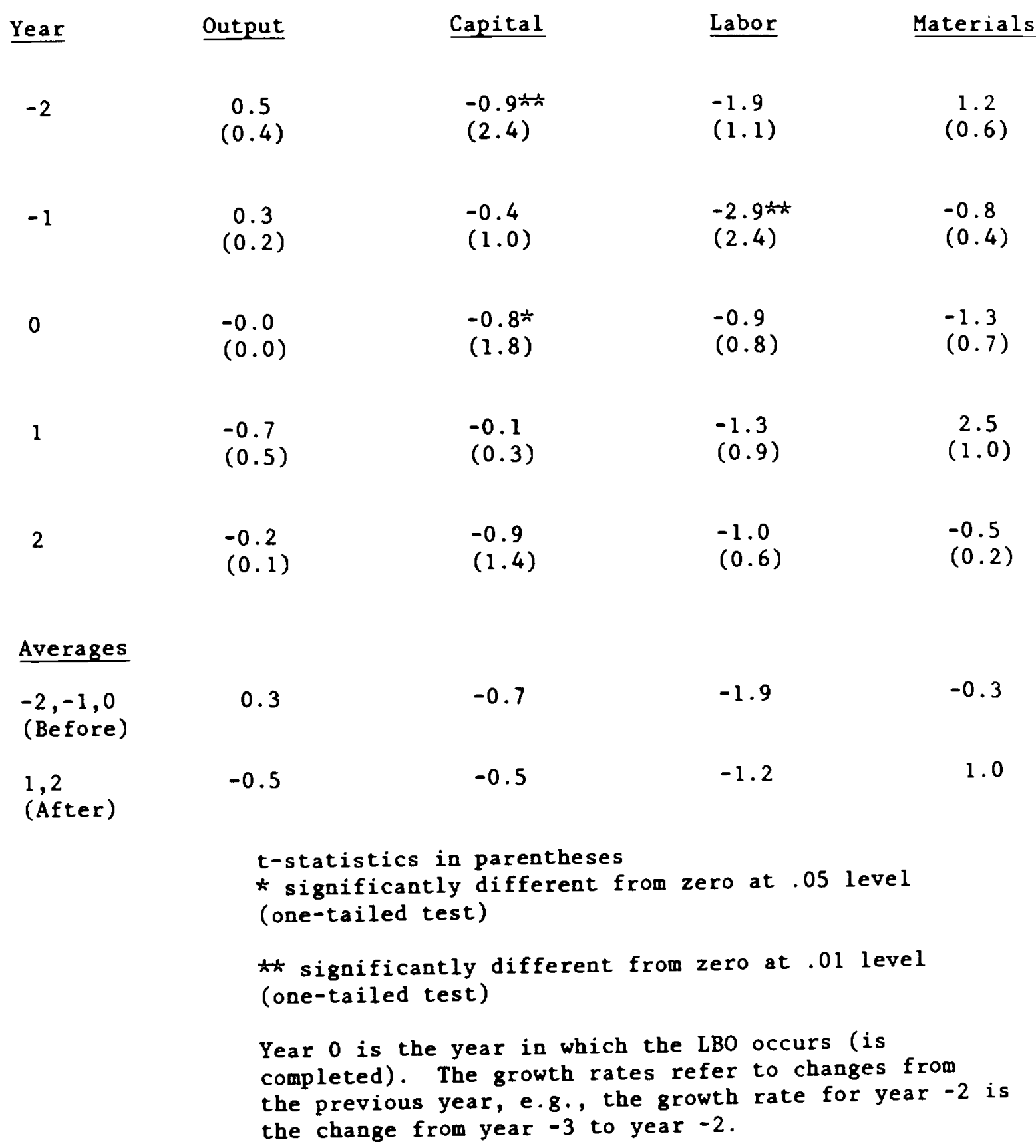




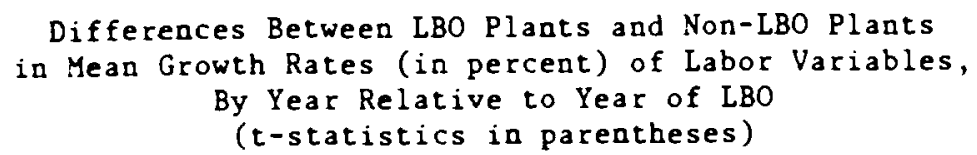

\begin{tabular}{|c|c|c|c|c|c|c|c|c|c|c|c|}
\hline \multirow[b]{3}{*}{ Year } & \multirow{2}{*}{\multicolumn{3}{|c|}{ Wage bill }} & \multirow{2}{*}{\multicolumn{3}{|c|}{ Employment }} & \multicolumn{3}{|c|}{ Annua 1 } & \multirow{3}{*}{$\frac{\frac{\text { Hourly }}{\text { wagerate }}}{\underline{\text { p }}}$} & \multirow{3}{*}{$\frac{\text { Annua 1 }}{\frac{\text { bours }}{\mathrm{P}}}$} \\
\hline & & & & & & & & ge rat & & & \\
\hline & $\underline{\mathbf{N}}-$ & $\underline{\mathbf{P}}$ & $\mathrm{N}-\mathrm{P}$ & $\underline{\mathbf{N}}$ & $\underline{P}$ & $\underline{N}-P$ & $\underline{N}$ & $\underline{\mathrm{P}}$ & $\underline{N-P}$ & & \\
\hline-2 & $\begin{array}{c}3.5 \\
(2.5)\end{array}$ & $\begin{array}{l}-0.6 \\
(0.7)\end{array}$ & $\begin{array}{c}4.1 \\
(3.0)\end{array}$ & $\begin{array}{c}1.3 \\
(1.2)\end{array}$ & $\begin{array}{l}-0.0 \\
(0.0)\end{array}$ & $\begin{array}{c}1.3 \\
(1.2)\end{array}$ & $\begin{array}{c}2.2 \\
(2.1)\end{array}$ & $\begin{array}{l}-0.6 \\
(1.2)\end{array}$ & $\begin{array}{c}2.8 \\
(2.3)\end{array}$ & $\begin{array}{l}-0.0 \\
(0.0)\end{array}$ & $\begin{array}{l}-1.6 \\
(1.4)\end{array}$ \\
\hline-1 & $\begin{array}{l}-2.6 \\
(2.3)\end{array}$ & $\begin{array}{l}-0.3 \\
(0.3)\end{array}$ & $\begin{array}{l}-2.3 \\
(2.4)\end{array}$ & $\begin{array}{l}-2.7 \\
(2.4)\end{array}$ & $\begin{array}{c}0.1 \\
(0.1)\end{array}$ & $\begin{array}{l}-2.8 \\
(2.7)\end{array}$ & $\begin{array}{c}0.1 \\
(0.8)\end{array}$ & $\begin{array}{c}-0.4 \\
(0.5)\end{array}$ & $\begin{array}{c}0.5 \\
(0.4)\end{array}$ & $\begin{array}{c}0.6 \\
(0.8)\end{array}$ & $\begin{array}{l}-2.7 \\
(2.2)\end{array}$ \\
\hline 0 & $\begin{array}{l}-3.1 \\
(3.1)\end{array}$ & $\begin{array}{l}-0.4 \\
(0.3)\end{array}$ & $\begin{array}{l}-2.7 \\
(2.1)\end{array}$ & $\begin{array}{l}-3.1 \\
(2.7)\end{array}$ & $\begin{array}{l}-0.3 \\
(0.4)\end{array}$ & $\begin{array}{l}-2.8 \\
(2.2)\end{array}$ & $\begin{array}{l}-0.0 \\
(0.0)\end{array}$ & $\begin{array}{l}-0.1 \\
(0.2)\end{array}$ & $\begin{array}{c}0.1 \\
(0.1)\end{array}$ & $\begin{array}{c}0.0 \\
(0.1)\end{array}$ & $\begin{array}{l}-0.8 \\
(0.7)\end{array}$ \\
\hline 1 & $\begin{array}{l}-3.4 \\
(2.3)\end{array}$ & $\begin{array}{c}0.8 \\
(0.5)\end{array}$ & $\begin{array}{l}-4.2 \\
(2.7)\end{array}$ & $\begin{array}{l}-3.3 \\
(2.4)\end{array}$ & $\begin{array}{l}-1.4 \\
(1.3)\end{array}$ & $\begin{array}{l}-1.9 \\
(1.3)\end{array}$ & $\begin{array}{c}-0.1 \\
(0.1)\end{array}$ & $\begin{array}{c}2.2 \\
(2.7)\end{array}$ & $\begin{array}{l}-2.3 \\
(1.5)\end{array}$ & $\begin{array}{c}1.7 \\
(1.9)\end{array}$ & $\begin{array}{c}-1.7 \\
(1.1)\end{array}$ \\
\hline 2 & $\begin{array}{l}-7.2 \\
(4.4)\end{array}$ & $\begin{array}{c}1.2 \\
(0.8)\end{array}$ & $\begin{array}{c}-8.4 \\
(4.8)\end{array}$ & $\begin{array}{l}-2.1 \\
(1.3)\end{array}$ & $\begin{array}{l}-0.3 \\
(0.3)\end{array}$ & $\begin{array}{l}-1.8 \\
(1.2)\end{array}$ & $\begin{array}{l}-5.1 \\
(3.6)\end{array}$ & $\begin{array}{c}1.5 \\
(1.8)\end{array}$ & $\begin{array}{l}-6.6 \\
(3.8)\end{array}$ & $\begin{array}{c}0.6 \\
(0.6)\end{array}$ & $\begin{array}{c}1.2 \\
(0.7)\end{array}$ \\
\hline
\end{tabular}

\section{Averages}

\begin{tabular}{|c|c|c|c|c|c|c|c|c|c|c|c|}
\hline $\begin{array}{l}\text { Before } \\
(-2,-1,0)\end{array}$ & -0.7 & -0.4 & -0.3 & -1.5 & -0.1 & -1.4 & 0.8 & -0.4 & 1.2 & 0.2 & -1.7 \\
\hline $\begin{array}{l}\text { Af ter } \\
(1,2)\end{array}$ & -5.3 & 1.0 & -6.3 & -2.7 & -0.9 & -1.8 & -2.6 & 1.9 & -4.5 & 1.2 & -0.3 \\
\hline $\begin{array}{l}\text { After- } \\
\text { Before }\end{array}$ & -4.6 & 1.4 & -6.0 & -1.2 & -0.8 & -0.4 & -3.4 & 2.3 & -5.7 & 1.0 & 1.4 \\
\hline
\end{tabular}


Table 10

Plants Closing in 1981:

Mean Deviation From Respective Industry Means of

Productivity Levels, Output Growth, and Employment Growth, 1972-81 (standard errors in parentheses)

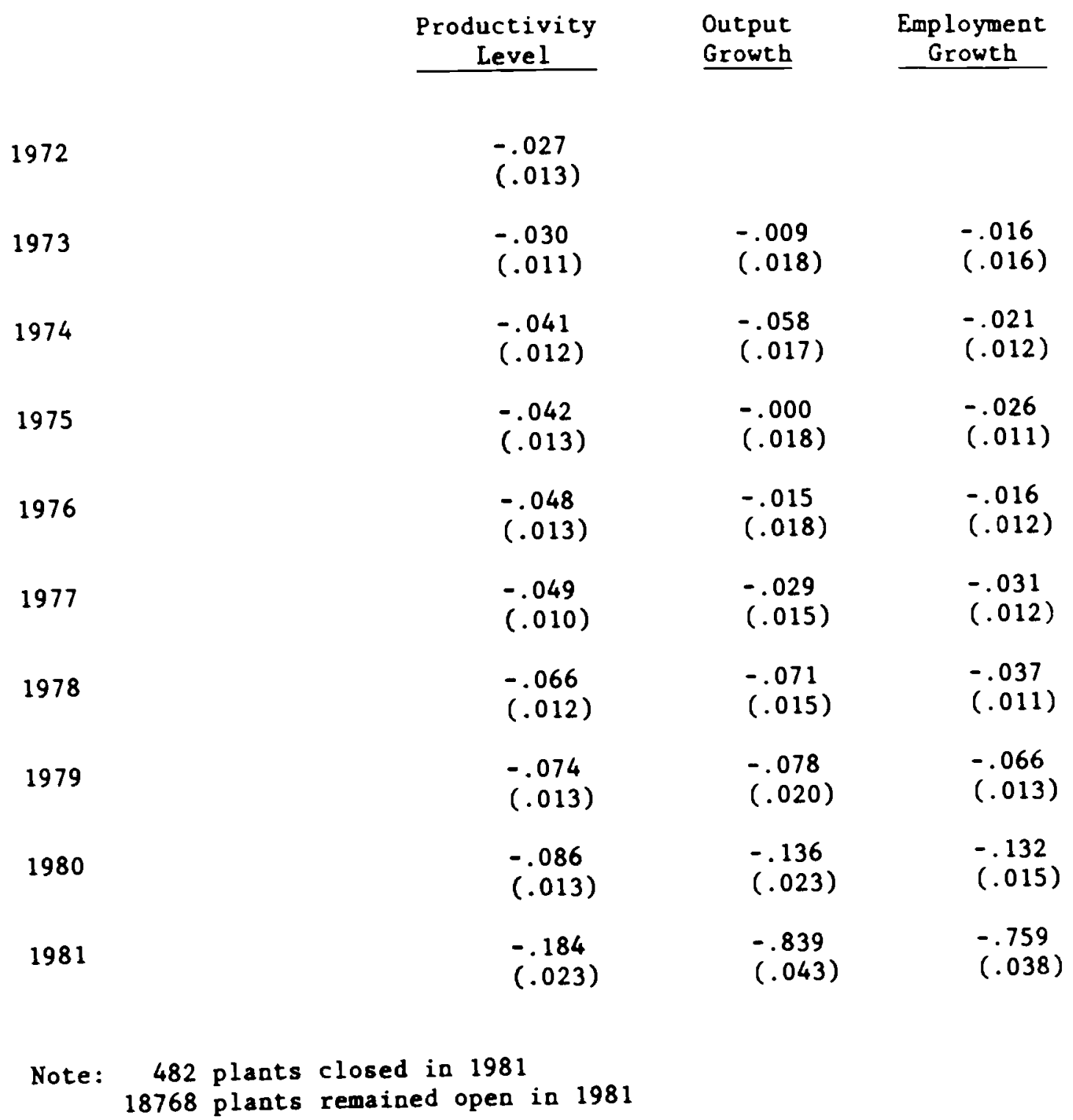


Table 11

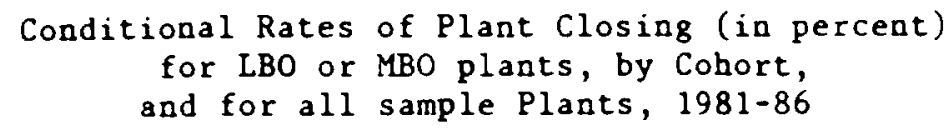

\begin{tabular}{|c|c|c|c|c|c|c|c|}
\hline Year & $\begin{array}{l}\text { All sample } \\
\text { Plants }\end{array}$ & $\begin{array}{c}1981 \text { LBO } \\
\text { Plants } \\
\end{array}$ & $\begin{array}{c}1982 \text { LBO } \\
\text { Plants } \\
\end{array}$ & $\begin{array}{c}1983 \text { LBO } \\
\text { Plants } \\
\end{array}$ & $\begin{array}{c}1984 \text { LBO } \\
\text { Plants } \\
\end{array}$ & $\begin{array}{c}1985 \text { LBO } \\
\text { Plants } \\
\end{array}$ & $\begin{array}{c}1986 \text { LBO } \\
\text { Plants } \\
\end{array}$ \\
\hline $\begin{array}{l}1981 \\
1982 \\
1983 \\
1984 \\
1985 \\
1986\end{array}$ & $\begin{array}{l}2.3 \\
2.9 \\
2.6 \\
1.6 \\
2.0 \\
1.9\end{array}$ & $\begin{array}{l}1.2 \\
7.0 \\
4.7 \\
2.3 \\
0.0 \\
3.5\end{array}$ & $\begin{array}{l}2.5 \\
0.8 \\
0.8 \\
1.7 \\
3.4\end{array}$ & $\begin{array}{l}1.9 \\
0.6 \\
1.3 \\
3.2\end{array}$ & $\begin{array}{l}1.9 \\
3.0 \\
3.0\end{array}$ & $\begin{array}{l}1.9 \\
4.3\end{array}$ & 1.2 \\
\hline & $\begin{array}{l}\text { All sample } \\
\text { Plants } \\
\end{array}$ & $\begin{array}{c}1981 \mathrm{MBO} \\
\text { Plants } \\
\end{array}$ & $\begin{array}{c}1982 \mathrm{MBO} \\
\text { Plants } \\
\end{array}$ & $\begin{array}{c}1983 \mathrm{MBO} \\
\text { Plants } \\
\end{array}$ & $\begin{array}{c}1984 \mathrm{MBO} \\
\text { Plants } \\
\end{array}$ & $\begin{array}{c}1985 \mathrm{MBO} \\
\text { Plants } \\
\end{array}$ & $\begin{array}{c}1986 \mathrm{MBO} \\
\text { Plants } \\
\end{array}$ \\
\hline $\begin{array}{l}1981 \\
1982 \\
1983 \\
1984 \\
1985 \\
1986\end{array}$ & $\begin{array}{l}2.3 \\
2.9 \\
2.6 \\
1.6 \\
2.0 \\
1.9\end{array}$ & $\begin{array}{r}0.0 \\
16.7 \\
0.0 \\
0.0 \\
0.0 \\
0.0\end{array}$ & $\begin{array}{l}0.0 \\
0.0 \\
0.0 \\
0.0 \\
6.3\end{array}$ & $\begin{array}{l}2.6 \\
0.9 \\
1.8 \\
2.6\end{array}$ & $\begin{array}{l}0.0 \\
5.0 \\
1.7\end{array}$ & $\begin{array}{l}1.8 \\
1.8\end{array}$ & 1.4 \\
\hline
\end{tabular}


Table 12

Mean R\&D Intensity: LBO firms vs. All R\&D Performers, 1978-1986

(1)

Mean R\&D Intensity of Intensity of All

Year LBO Firms
(2)

Mean R\&D

R\&D Performers $\quad(1) \div(2)$

A. R\&D Expenditure $\div$ Sales

$\begin{array}{llll}1978 & 1.2 \% & 2.9 \% & .41 \\ 1979 & 1.2 & 2.9 & .41 \\ 1980 & 1.4 & 3.0 & .47 \\ 1981 & 1.4 & 3.4 & .41 \\ 1982 & 1.6 & 3.5 & .46 \\ 1983 & 1.7 & 3.7 & .46 \\ 1984 & 1.5 & 3.6 & .42 \\ 1985 & 1.5 & 3.7 & .41 \\ 1986 & 1.8 & 3.4 & .53\end{array}$

B. R\&D Scientists \& Engineers $\div$ Total Employment

$\begin{array}{llll}1978 & 1.4 & 3.1 & .45 \\ 1979 & 1.4 & 3.3 & .42 \\ 1980 & 1.5 & 3.2 & .47 \\ 1981 & 1.5 & 3.3 & .45 \\ 1982 & 1.5 & 3.8 & .39 \\ 1983 & 1.5 & 3.9 & .38 \\ 1984 & 1.5 & 3.8 & .39 \\ 1985 & 1.7 & 4.0 & .43 \\ 1986 & 1.7 & 3.6 & .47\end{array}$




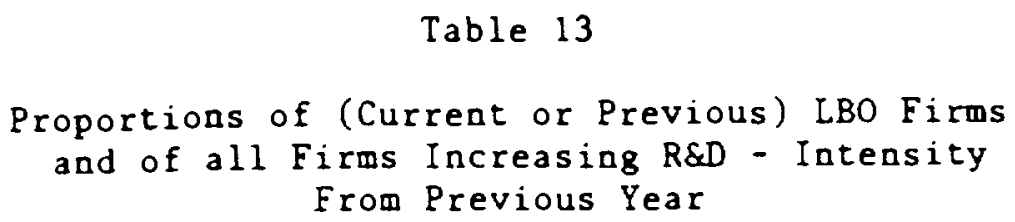

All R\&D-

Performing Firms

1981

1982

1983

1984

29

1985

48

1986
29

38

$20 \%$

55

30

31 